\title{
Delta size variability at Lake General Carrera, Patagonia
}

\author{
*Rebecca M.E. Williams', B.M. Hynek ${ }^{2,3}$
}

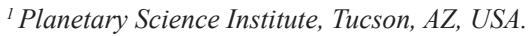

williams@psi.edu

${ }^{2}$ Laboratory for Atmospheric and Space Physics, University of Colorado at Boulder, Boulder, Colorado, USA. hynek@lasp.colorado.edu

${ }^{3}$ Department of Geological Sciences, University of Colorado at Boulder, Boulder, Colorado, USA.

*Corresponding author: williams@psi.edu

\begin{abstract}
Punctuated lake level drops at Lake General Carrera, Chile, over the last $\sim 13 \mathrm{ka}$ are recorded in multiple stacked deltas that differ in scale. Fifteen delta terrace suites are studied to examine the factors that influence deposit morphology. Surprisingly, the pronounced longitudinal precipitation gradient is inversely correlated with the observed variations in delta size. We find the drainage basins with long-term water storage in glaciers are associated with larger deltas. In these cases, the added contribution of rare, high-magnitude ice meltwater release events $\left(>600 \mathrm{~m}^{3} / \mathrm{s}\right)$ is suggested as the differential driver to enhance delta growth. The overall progradation rate is modest $(0.2-1 \mathrm{~m} / \mathrm{yr})$, and appears to have slowed over time. For the youngest deltas, we estimate the range in the intermittency factor, a dimensionless measure of the frequency of floods, is $1 \times 10^{-2}$ to $4 \times 10^{-5}$. Our results illustrate the natural variability of delta growth in a small region $\left(<20,000 \mathrm{~km}^{2}\right)$, and better characterize understudied glaciogenic deltas.
\end{abstract}

Keywords: Geomorphology, Fluvial, Hydrology, Floods, Sedimentation, Catchment, Patagonia.

RESUMEN. Variabilidad del tamaño de los deltas en el lago General Carrera. Las caídas puntuales del nivel del agua en el lago General Carrera, Chile, durante los últimos $\sim 13$ ka están registrados en los múltiples deltas sobrepuestos y que difieren en escala. Se estudiaron quince conjuntos de terrazas de deltas para examinar los factores que influyen en la morfología de los depósitos. Sorprendentemente, el pronunciado gradiente de precipitación longitudinal presenta una relación inversa con las variaciones del tamaño del delta. Se observó que las cuencas de drenaje con almacenamiento de agua a largo plazo en los glaciares están asociadas con deltas de mayor tamaño. En estos casos, se sugiere que la contribución adicional de eventos excepcionales de liberación de agua de deshielo de gran magnitud $\left(>600 \mathrm{~m}^{3} / \mathrm{s}\right)$ contribuyen a incrementar el crecimiento del delta. La tasa de progradación general es modesta (0,2-1 m/año) y parece haber disminuido con el tiempo. Para los deltas más jóvenes, estimamos que el rango en el factor de intermitencia, una medida de la frecuencia de las inundaciones, es de $1 \times 10^{-2}$ to $4 \times 10^{-5}$. Nuestros resultados ilustran la variabilidad natural del crecimiento de los deltas en una región pequeña $\left(<20.000 \mathrm{~km}^{2}\right)$ y caracterizan mejor los deltas glaciogénicos poco estudiados. 


\section{Introduction}

Sedimentary deposits accumulate where a river enters a basin (alluvial fan) or body of water (delta). Fan deposits are dynamic landforms that record environmental change reflecting regional hydrologic and climatic conditions (Blair and McPherson, 1994; Stock, 2013). The resulting fan shape and scale is a response to changes in sedimentary input and base level (e.g., Postma, 1990; Bhattacharya, 2006). How these factors influence the fan form is assessed at Lake General Carrera in Patagonia where the climate and water availability varied around the upper Río Baker basin since the Last Glacial Maximum.

Fifteen delta terrace suites are studied around the perimeter of Lake General Carrera in southern Chile (Fig. 1). Located along the $\sim 46.5^{\circ} \mathrm{S}$ parallel, the elongated lake ( $130 \mathrm{~km}$ wide) is bordered by terrain that transitions from mountain to steppe (Bourgois et al., 2016; Bendle et al., 2017). The Andes Mountains encircle the western half of the lake and are the natural cause of significant, ten-fold differences in annual precipitation and catchment size (Garreaud et al., 2013; Krogh et al., 2015). Within this geographic setting, the stepped deltas developed during a series of lake lowering events since the breakup of the Patagonian Ice Field $\sim 15 \mathrm{ka}$ (Davies et al., 2020). As a result of this lake regression, the sedimentary architecture of ancient deltas are exposed (Bell, 2008, 2009) and show temporal changes in flow magnitude. Lake General Carrera is a natural experiment to examine factors in delta formation caused by punctuated lake level drops in a cold climatic setting.

We evaluated the relative role of catchment characteristics and micro-climate on water supply and delta morphology. Our analysis demonstrates that catchment size and precipitation amount are insufficient explanations for the range of delta sizes observed. We find the largest deltas are associated with basins that had greater glacial retention. This correlation between delta size and catchment water storage is also manifested in the exposed topset deposits of ancient, perched deltas that record short- and longterm flood variability. Using available streamflow

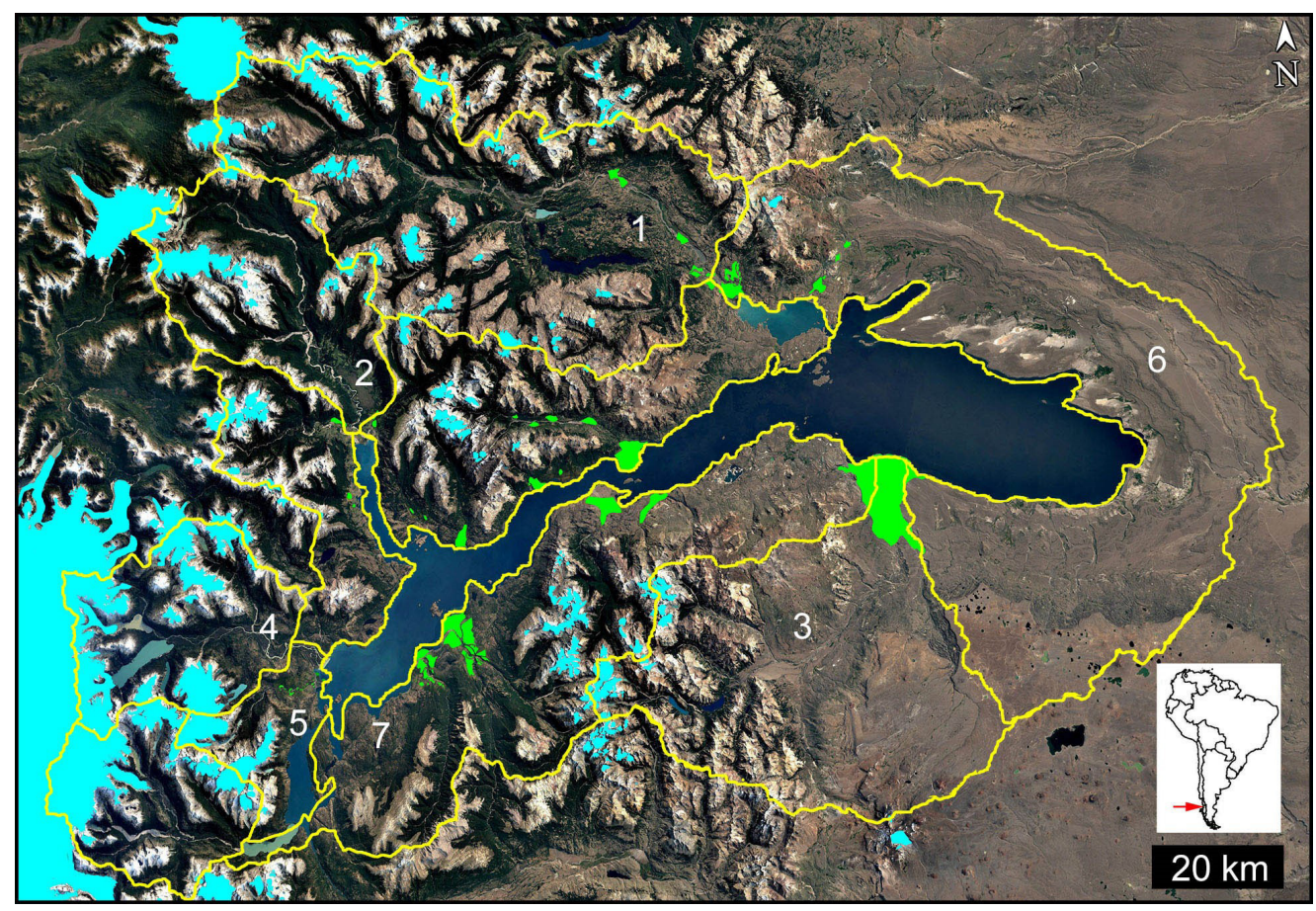

FIG. 1. Context map of study region with the sub-basins in the Río Baker basin outlined in yellow and labeled by white numbers (Krogh et al., 2015; Some sub-basins are unassigned). Location is marked by red arrow on inset. Overlain features, as mapped by Davies et al. (2020), include deltas in green, and the modern extent of glaciers in light blue. Image centered near $46.5^{\circ} \mathrm{S}$, $72.0^{\circ} \mathrm{W}$. Image Credit: GoogleEarth. 
and deposit age constraints, we estimate the range of development rates that encompass the multiple variables influencing delta formation. Furthermore, this characterization of glaciogenic lacustrine deltas at Lake General Carrera fills a knowledge gap within the broader catchment-fan system.

\section{Background}

\subsection{Lake General Carrera history}

Several superimposed lacustrine deltas are present along the shore of the Lake General Carrera, a lake that straddles the Chile-Argentina border (Figs. 1 and 2). The lake is the second largest in South America, and it covers an area of $1,900 \mathrm{~km}^{2}$ with a maximum depth of $\sim 600 \mathrm{~m}$. The current lake level is at an elevation of $\sim 201$ meters above sea level.

Lake General Carrera formed as a consequence of glacial retreat. The Patagonian Ice Sheet in the southern Andes Mountains has changed spatial extent multiple times throughout the Quaternary (Meier et al., 2018; Davies et al., 2020). During the Last Glacial Maximum, the ice sheet extended $>1,800 \mathrm{~km}$ between $38^{\circ} \mathrm{S}$ and $56^{\circ} \mathrm{S}$ latitude. At times, ice lobes advanced eastward to the Argentine steppe filling east-west trending depressions. During deglaciation, which began $\sim 15 \mathrm{ka}$, freshwater lakes formed in these depressions (Turner et al., 2005). As the ice field shrunk in size, meltwater fed an ancestral lake (Paleolake Deseado) with an original eastern spillover to the Atlantic Ocean (Glasser et al., 2016; Davies et al., 2020). Continued decline of the ice fields led to a drainage reversal, with a western route to the Pacific Ocean. Patagonian lakes assumed their current extent around the time of this western breach (Davies et al., 2020).

Early in the Lake General Carrera history, glacial moraines damned the eastern edge. Bell (2008) proposes that the highest delta levels at Río Dunas $(650,600,500 \mathrm{~m}$ a.s.1.) formed during the time when the lake drained to the east via

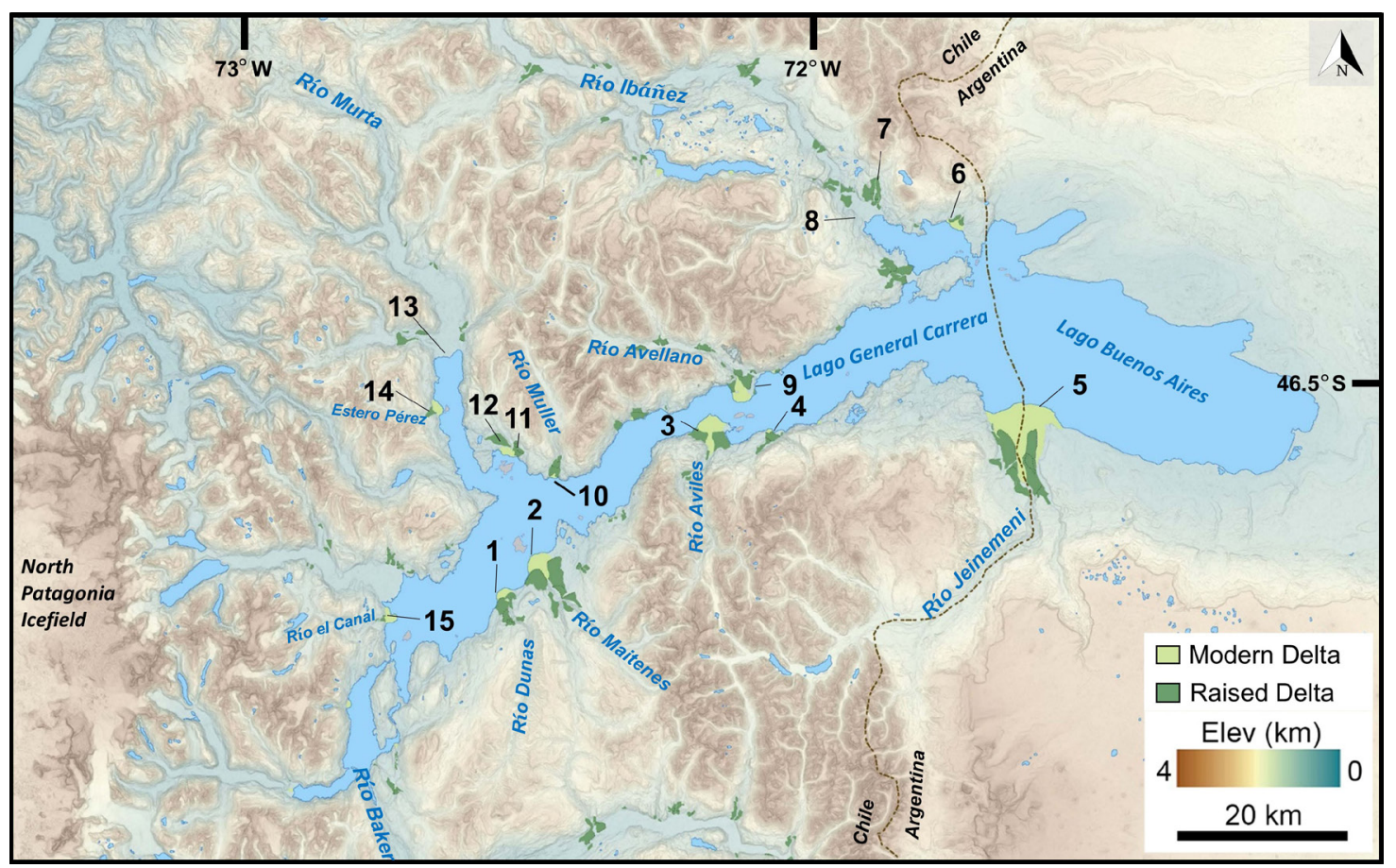

FIG. 2. Location map of Lake General Carrera deltas included in this study. Deltas are marked by number counter-clockwise around the lake. 1. Maitenes; 2. Dunas; 3. Fachinal; 4. Santa Clara; 5. Chile Chico; 6. Moncada; 7. Lechoso; 8. Ibáñez; 9. Avellano; 10. Muller; 11. Sánchez-west; 12. Sánchez-east; 13. Murta; 14. Estero Pérez; 15. Río el Canal. Mapped deltas (shades of green) and basemap are from Bendle et al. (2017). Only raised deltas are shown at Murta and Ibáñez rivers because glaciofluvial outwash have modified the modern delta. 
Río Deseado (370 m a.s.l. at Perito Moreno). On the western side, glacier retreat resulted in the subdivision of the Patagonia Ice Sheet into two icefields, the Northern and Southern Patagonian Icefields (Fig. 2). After this ice retreat of $\sim 100 \mathrm{~km}$, a western outlet through Río Baker formed; this drainage reversal occurred at $12.8 \mathrm{ka}$ (13.6-16.3 ka; Turner et al., 2005).

Radiometrically dated samples from the margins of Lake General Carrera provide general age constraints on events. High elevation (450-600 m a.s.1.) shales interpreted as seasonal lacustrine deposits (varves) are dated to $13 \mathrm{ka}$ (Turner et al., 2005), and are presumed to be the maximum age of Lake General Carrera deltas. On the first terrace level at Río Dunas, a volcanic ash bed that originated from Hudson Volcano is dated at $6.7 \mathrm{ka}$ (Narnjo and Stern, 1998). Cosmogenically dated boulders $(6.2 \pm 0.8 \mathrm{ka})$ at Fachinal predate the lake drop from $320 \mathrm{~m}$ a.s.l. to the present day level (Douglass et al., 2005).

Collectively, the complex lake history included major lake-level drops of $\sim 100 \mathrm{~m}$ occurring at intervals of hundreds to thousands of years, with smaller $<10 \mathrm{~m}$ drops over periods of years to decades (Bell et al., 2008). The controlling factors on lake level vary by timescale. Bell (2008) proposed that seasonal punctuated lake lowering resulted in small elevation drops. Large lake level drops occurred rarely due to breaching of natural barriers at the two outlets.

The stacked deltas are the products of sediment influx onto a shoreline responding to catastrophic falls in lake level and are almost exclusively located along the Chilean portion of the lake (the Argentinian side of the lake is called Lake Buenos Aires; Bell, 2008, 2009). Over the last 13,000 years, these perched deltas formed as lake level fell several hundred meters in a punctuated sequence of events (Douglass et al., 2005; Bell, 2008). Lake General Carrera is a rare example with multiple, exposed stacked deltas that formed in a regressive setting.

The maximum Lake General Carrera highstand corresponds to a level at least $200 \mathrm{~m}$ above the present lake level, and potentially as much as $400 \mathrm{~m}$ a.s.l. (Turner et al., 2005; Davies et al., 2020) (alternatively, some of these high elevation deposits are interpreted as river terraces in Bourgois et al., 2016). Subsequent deltas formed associated with stable lake levels that occurred periodically during the overall retreat of the lake to its present-day configuration, resulting in entrenchment of the older delta steps.

Each of the steps in the Lake General Carrera deltas marks a stable lake level and is characterized by a delta and associated beach embayment. The deltas have a classic Gilbert form with a braided river on the top surface and a steeply inclined front (Fig. 3). (In terms of nomenclature, this variety of landform has also been termed an alluvial fan delta, or braid delta e.g., McPherson et al., 1987; Postma, 1990). The deltas at Lake General Carrera are river-dominated deltas with a classic triangular shape (Bhattacharya, 2006). Deltas are fed by steep-gradient rivers (Type-A feeder, Postma, 1990). Coarse bedload sedimentation is concentrated on the lower delta plain and delta front. Prolonged lake level highstands gave ample time for development of extensive subhorizontal delta plains.

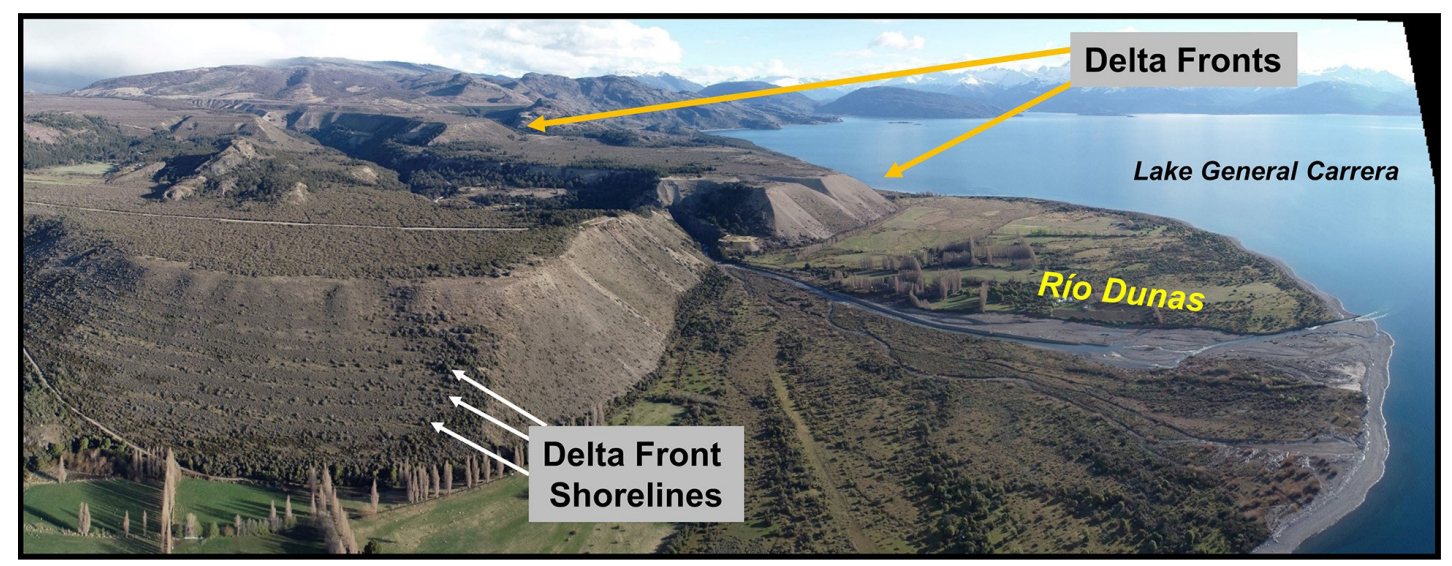

FIG. 3. Oblique aerial view of the lower Río Dunas stepped lacustrine delta terraces. 


\subsection{Climate and hydrology}

The upper Río Baker basin contains four Köppen climate classes transitioning eastward from cold to temperate to dry: the "Polar Highland Ice Caps" (EFh) for the Northern Patagonia Ice Field and surrounding areas; the "Maritime Sub Arctic" (Cfc) and "Maritime Temperate" $(\mathrm{Cfb})$ classes cover the western and central portion of Lake General Carrera, respectively; and the "Middle-Latitude, Semi-Arid Steppe with Winter Precipitation" (BSk) encompasses the eastern portion of the study region (Peel et al., 2007). At a more granular scale, sub-basins of the upper Río Baker based on drainage divides and micro-climates were delineated by Krogh et al. (2015; Fig. 1).

There is a pronounced west to east precipitation gradient due to the orographic effect. Mean annual precipitation on the western side of the Andean main divide can exceed 5-10 m/yr (Garreaud et al., 2013). Semi-arid conditions on the steppe are associated with precipitation of $<0.3 \mathrm{~m} / \mathrm{yr}$ (Garreaud et al., 2013).

Meteorological and stream gauges are preferentially situated in populated areas located at lower elevations (Table 1). Data is from the Chilean National Meteorological Office (Dirección Meteorológica de Chile) and the Chilean Water Authority (Dirección General de Aguas), respectively, and is sourced in this study from the literature, as cited. Rain gauges in the study region record the longitudinal precipitation gradient (Fig. 4A). The subset of stations along the periphery of Lake General Carrera show an overall decrease in annual precipitation to the east ( 1.3 to $0.2 \mathrm{~m} / \mathrm{yr}$ ). Within this trend there is also minor latitudinal differences: the northern side of the lake receives slightly more precipitation than the south side, as reflected in the two stations located at $\sim 72.7^{\circ} \mathrm{W}$ (Murta versus Puerto Guadal), and gauges between $71.7^{\circ}$ and $72.0^{\circ} \mathrm{W}$ (Puertos Ibáñez versus Chile Chico) (Table 1).

There are no high-elevation weather stations, and therefore an absence of data on precipitation in the catchment. Prior researchers have noted that observed precipitation at weather stations (preferentially located at low elevations) is not a predictive indicator for river hydrographs (Krogh et al., 2015; Duissilant et al., 2012). Based on a hydrologic model, Krogh et al. (2015) estimate nearly one-third of the total precipitation is from snowfall and approximately
TABLE 1. AVERAGE ANNUAL PRECIPITATION FROM METEOROLOGICAL STATIONS IN THE RÍO BAKER BASIN

\begin{tabular}{|c|c|c|c|}
\hline \multirow{3}{*}{ Site } & \multicolumn{2}{|c|}{$\begin{array}{c}\text { Approximate station } \\
\text { location }\end{array}$} & \multirow[b]{2}{*}{ Precipitation " } \\
\hline & Latitude & Longitude & \\
\hline & ${ }^{\circ} \mathbf{S}$ & ${ }^{\circ} \mathbf{W}$ & $\mathbf{m m} / \mathbf{y r}$ \\
\hline Puerto Bertrand ${ }^{\mathrm{b}}$ & 47.016 & 72.827 & 1,280 \\
\hline Puerto Guadal ${ }^{\text {b }}$ & 46.845 & 72.703 & 680 \\
\hline Río Murta ${ }^{\mathrm{b}}$ & 46.455 & 72.673 & 1,175 \\
\hline Chile Chico $^{\text {b }}$ & 46.544 & 71.657 & 220 \\
\hline Río Ibáñez ${ }^{\text {b }}$ & 46.293 & 71.938 & 817 \\
\hline Río Jeinimeni ${ }^{\text {b }}$ & 46.544 & 71.657 & 407 \\
\hline Lago Vargas & 47.672 & 73.099 & 1,707 \\
\hline Baker at Nadis & 47.522 & 73.030 & 689 \\
\hline Baker at Colonia & 47.404 & 72.901 & 636 \\
\hline Baker at Bertrand Lake & 47.066 & 72.799 & 647 \\
\hline Río del Salto & 47.287 & 72.724 & 851 \\
\hline Baker at Chacabuco & 47.133 & 72.697 & 678 \\
\hline Río Chacabuco & 47.115 & 72.605 & 557 \\
\hline Río Cochrane & 47.254 & 72.581 & 394 \\
\hline Villa Castillo & 46.018 & 72.152 & 580 \\
\hline Entrada Baker & 47.182 & 71.974 & 380 \\
\hline
\end{tabular}

a Dussaillant et al. (2012)

${ }^{\mathrm{b}}$ Station within upper Río Baker Basin

one-quarter of the water in rivers originates from snowmelt.

River discharge also exhibits a west-to-east decline in magnitude, consistent with the precipitation pattern. Only three rivers at Lake General Carrera have stream gauges: Río Murta, Río Ibáñez and Río Jeinimeni. Table 2 reports the mean annual discharge for these rivers, as well as for Río Baker (Krogh et al., 2015). Mean annual discharge $\left(Q_{m a}\right)$ for these rivers ranges from 27 to $160 \mathrm{~m}^{3} / \mathrm{s}$, significantly less than the $\sim 570$ $\mathrm{m}^{3} / \mathrm{s}$ for the larger Río Baker.

Over a 23 year record of stream gauge data for the largest river entering Lake General Carrera, Río Ibáñez recorded typical mean monthly discharge values from 100 to $225 \mathrm{~m}^{3} / \mathrm{s}$ with peak flows occuring in late spring and summer (Dussaillant et al., 2012). For this period between 1985 and 2008, there are rare months that exceeded $300 \mathrm{~m}^{3} / \mathrm{s}$ for the mean monthly discharge (Dussaillant et al., 2012). 

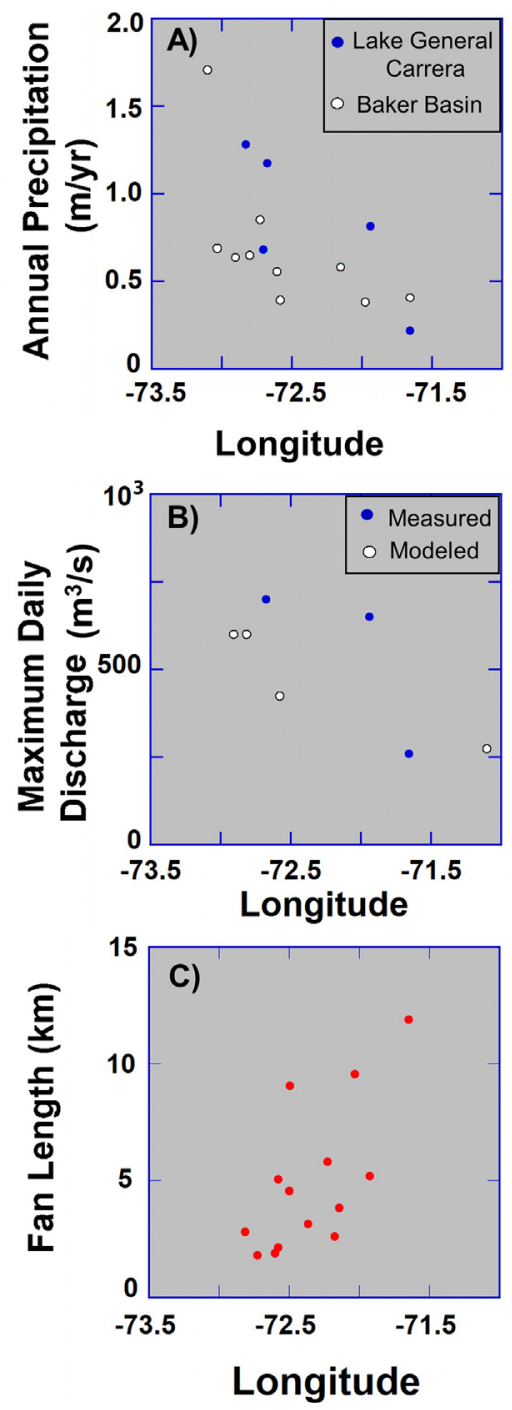

FIG. 4. Examples of general longitudinal trends across the Lake General Carrera region. A. Plot of annual precipitation data from meteorological stations in the region as reported in Dussaillant et al. (2012). B. Maximum daily river discharge data from stream gauge stations (blue dots) and model-derived values (red dots) are displayed from a 2 year period during 2004 to 2006 (Krogh et al., 2015). C. Total length of delta terrace sequences increases to the east.

Continuous baseflow at Lake General Carrera rivers is a few tens of cubic meters per second. Maximum daily discharge ranges from $260 \mathrm{~m}^{3} / \mathrm{s}$ at Río Jeinimeni, to roughly $700 \mathrm{~m}^{3} / \mathrm{s}$ at Río Murta and Río Ibáñez (Fig. 4B). To fill in the gaps in the observational record, Krogh et al. (2015) formulated
TABLE 2. MEAN ANNUAL DISCHARGE FROM STREAM GAUGE STATIONS IN THE RÍO BAKER BASIN.

\begin{tabular}{|c|c|c|c|c|}
\hline \multirow{2}{*}{ River } & \multirow{2}{*}{$\begin{array}{l}Q_{m a}{ }^{1} \\
\mathbf{m}^{3 / \mathbf{s}}\end{array}$} & \multicolumn{2}{|c|}{ Record length } & \multirow{2}{*}{$\begin{array}{c}\text { Basin size } \\
\mathbf{k m}^{2}\end{array}$} \\
\hline & & yrs & Interval & \\
\hline Río Baker & 568 & 51 & $1963-2014$ & 15,997 \\
\hline Río Murta & 93.5 & 29 & $1985-2014$ & 896 \\
\hline Río Ibáñez & 158 & 44 & $1970-2014$ & 2,407 \\
\hline Río Jeinimeni & 27 & 9 & 1995-2004 & 1,395 \\
\hline
\end{tabular}

$Q_{m a}$ is the mean annual discharge.

${ }^{1}$ Krogh et al., 2015.

${ }^{2}$ Duissalant et al., 2012.

a hydrologic model that factored in micro-climate conditions for each sub-basin in the upper Río Baker. Their model-derived daily river discharge values are within the observational range at Lake General Carrera rivers (Table 3).

In Patagonia, the highest discharge flows are due to ice-release events (called jökulhlaup or glacier outburst floods). A few of these catastrophic flow events are documented in the Río Baker basin, as described below. These accounts provide context on the frequency and magnitude of these rare flows, however jökulhlaup events have not been measured on rivers that terminated in Lake General Carrera.

A multi-decade stream gauge record for Río Baker, which has the highest discharge for all Chilean Rivers, provides some context on flow magnitude. Mean annual discharge for Río Baker is $\sim 1100 \mathrm{~m}^{3} / \mathrm{s}$ (Dussaillant et al., 2012). Bankfull discharge for 5-year and 10-year recurrence interval Río Baker floods is $781 \mathrm{~m}^{3} / \mathrm{s}$ and $1096 \mathrm{~m}^{3} / \mathrm{s}$, respectively (Ulloa et al., 2018). In 2008 and 2009, glacier outburst events recorded at Río Baker were $>3500 \mathrm{~m}^{3} / \mathrm{s}$, an increase of $\sim 1000 \mathrm{~m}^{3} / \mathrm{s}$ over rain on snow events, and $\sim 2000 \mathrm{~m}^{3} / \mathrm{s}$ greater than typical rain-fed flow discharge (Dussaillant et al., 2010, 2012). Elsewhere in the Río Baker system, flood reconstruction in the Colonia Valley indicates flood discharges as high as $16,000 \mathrm{~m}^{3} / \mathrm{s}$ may have occurred (Dussaillant et al., 2010). Historical accounts of extreme flows in the southern Aysén region indicate they occur on century timescales, although some river systems may have more frequent events (once per decade), or the frequency may be increasing with the growing ice retreat rate associated with climate change (Dussaillant et al., 2010, 2012). 
TABLE 3. DAILY DISCHARGE IN THE UPPER RÍO BAKER.

\begin{tabular}{ccccl}
\hline & \multicolumn{3}{c}{ Minimum } & \multicolumn{2}{c}{ Maximum } & \\
\cline { 2 - 3 } $\begin{array}{c}\text { Sub- } \\
\text { Basin }\end{array}$ & $\mathbf{m}^{3} / \mathbf{s}$ & $\mathbf{m}^{3} / \mathbf{s}$ & Source & Reference \\
\hline 1 & 20 & 650 & Stream gauge & Krogh et al., 2015. \\
2 & 60 & 700 & Stream gauge & Krogh et al., 2015. \\
3 & 10 & 260 & Stream gauge & Krogh et al., 2015. \\
4 & 20 & 600 & Model & Krogh et al., 2015. \\
5 & 40 & 600 & Model & Krogh et al., 2015. \\
6 & 10 & 275 & Model & Krogh et al., 2015. \\
7 & 15 & 425 & Model & Krogh et al., 2015. \\
\hline
\end{tabular}

$Q_{d d}$ is the daily discharge

\section{Methods and data}

Our objective is to elucidate the climatic and hydrologic forcing factors that influence delta formation at Lake General Carrera. We studied the delta morphologic and sedimentologic attributes with particular attention to the temporal changes in water source. Systematic measurements of landform scale are made at 15 deltas around the lake with satellite-derived image and topographic data. In situ observations were made at select deltas to further characterize small-scale geomorphic attributes and sedimentology.

\subsection{Delta and catchment dimensions at Lake General Carrera}

We used high resolution satellite images and topography of the Lake General Carrera site from Google Earth Pro to characterize dimensions of the contributing basin and delta terraces. Catchment area is based on the perimeter defined by the topographic divide connected to the active delta apex. Delta area is measured at each site with consideration of lateral extent as mapped in previous studies (Bell, 2008; Bourgois et al., 2016), with an emphasis on Bendle et al. (2017). Delta terraces are numbered sequentially with $\mathrm{T} 1$ for the modern (active) delta and increasing for perched terraces (T2-T7). Terrace levels greater than T6 are controversial (e.g., Bourgois et al., 2016 interprets as river terraces) and are excluded from measurement (area and length). We measured the average radial delta length (apex to toe) at three tracks for each delta and follow the convention used in the Bendle et al. (2017) geomorphic map of grouping the older terrace levels together (referred to here as $\mathrm{T} 2+)$. The $\mathrm{T} 1$ length is measured from the water to the projected extent of the eroded $\mathrm{T} 2$ terrace. This approach yields a minimum lateral length ( $\mathrm{T} 1$ and total length).

Active delta (T1) volume estimates are based on topographic data from a $1 \mathrm{~m} /$ pix digital elevation model from the Digital Globe Constellation satellite. We assume an idealized pie-wedge planform shape for the delta. The delta volume $(V)$ is computed using the equation for a semicone,

$$
V=P * \frac{1}{6}\left[\pi r^{2} h\right]
$$

with the measured radial length $(r)$ and relief (h) as inputs, and scaled by the planform shape (e.g., $P=$ percentage of azimuth dispersion from fan apex where $=1.0$ for $180^{\circ},=0.5$ for $90^{\circ}$, and $=$ 0.25 for $\left.45^{\circ}\right)$. The fan volume estimate is sensitive to the thickness $(h)$ of the deposit (Giles, 2010). For the youngest deltas at Lake General Carrera that developed during the current lake highstand, the role of pre-existing topography is likely minimal such that this idealized shape is a good approximation of the actual deposit volume.

\subsection{Site sedimentology observations}

Field observations were conducted in November 2018 at sites associated with the Dunas, Maitenes and Fachinal deltas. We documented the sedimentology of the superimposed fan deltas including their sedimentary structures, depositional facies, and grain sizes. Bedding geometries and grain size distribution are used to identify facies and depositional environment. Systematic grain size data were collected at each road-accessible delta level visited. Following standard protocol, a detailed pebble count of the long-axis of 100 clasts was made to determine a statistical sample of grain size, and report the largest (taken as the $84^{\text {th }}$ percentile size, $\mathrm{D}_{84}$ ) particle sizes (Wolman, 1954). We supplemented in situ grain size analysis with distal imaging of outcrops where maximum grain size was estimated based on scaleable references (sheep in one case) or by computing pixel scale based on distance to outcrop. 
Prior in situ study of the Lake General Carrera lacustrine deltas focused on the sequence along Río Dunas (Bell, 2008, 2009). Bell (2009) characterized the clastic debris in the Dunas delta, noting that the rock type proportion reflects bedrock distribution in the catchment: dominantly felsic volcanic (70\%) with some quartz schist (20\%) and marine sandstone $(10 \%)$. Further, that study identified sedimentary facies associated with specific depositional environments within the delta, a classification we adopted for this study: topsets, foresets and beach bars. Absent properly oriented vertical cross-section exposure to identify bedding geometry, it can be difficult to differentiate topsets from foresets. We assume that clasts found on the delta top are topsets, unless there is additional field observations that warrant a different classification.

\subsection{Discharge}

As detailed in section 2.2, the measured maximum daily discharge for tributary rivers in the upper Río Baker basin ranges from 260-700 m³/s (Krogh et al., 2015). We estimate flood discharge at two sites without stream gauges, Río Maitenes and Río Dunas, using two methods. First, we consider a crude discharge estimate based on river geometry. Channel width measurements are classified as confined river at the fan apex, or active tracts on the fan. Equation 2 is a linear regression of bankfull discharge as a function of channel width, $w$, for a global dataset of 654 rivers derived by Dietrich et al. (2017; their Equation 28.21) based on data from Li et al. (2015) and Trampush et al. (2014).

$Q_{w}=0.20 w^{1.66}$

(Equation 2)

The second approach is a physics-based threshold discharge $\left(Q_{T}\right)$ to mobilize sediment of a given grain size $\left(D_{84}\right)$ based on slope $(S)$, and width:

$$
Q_{T}=F w S^{-1.65} D_{84}^{1.5} g^{0.5} \ln \left(0.471 S^{-0.75} F\right)
$$

(Equation 3)

where $F$ is a combination term to account for relative density and grain roughness scale (see full details in Dietrich et al., 2017 for their equation 28.13). We use a representative size of the coarsest transported clast size from our sedimentological survey for the eighty-fourth percentage of grain size by volume term, $D_{84}$.

\subsection{Intermittency factor}

Paola et al. (1992) introduced the term intermittency factor to quantitatively characterize system deposition, which largely occurs during infrequent floods. Intermittency factor is the proportion of total time (temporal window for development) needed to transport the sediment load assuming the case where only continuous bankfull flows occurred. In this work, we compute the intermittency factor, $I_{f}$, as the ratio of time for deposition $\left(T_{d}\right)$ to total time $\left(T_{t}\right)$, where deposition time equals the delta volume divided by the bankfull sediment discharge $\left(\mathrm{Q}_{\text {sed bf }}\right)$ :

$I_{f}=\frac{T_{d}}{T_{t}}=\frac{\left(V / Q_{s e d b f}\right)}{T_{t}}$

(Equation 4)

We adopt input values for the variables that generally yield larger intermittency values to explore this end member case. The total time is constrained by radiometric dating studies. For flood discharge $(Q)$, we adopt the maximum daily discharge reported in Krogh et al. (2015; Table 3) where available. For deltas located in undefined sub-basins, a representative value of $100 \mathrm{~m}^{3} / \mathrm{s}$ is assumed, a conservative value compared to the maximum daily discharge in the upper Río Baker basin (Fig. 4B). We conservatively assume a bankfull sediment discharge value of $0.1 \%$ of seasonal flood discharge $\left(Q_{w}\right.$ or $\left.Q_{T}\right)$ that corresponds with lower values in floods (median value for gauged rivers in Hayden et al., 2021).

\subsection{Temporal changes in ice coverage within the catchment}

Maps of the spatial extent of modern glaciers (Bendle et al., 2017) as well as reconstructions of ice cover in Patagonia (called PATICE) from Davies et al. (2020) are used to assess ice position over time in the catchments. Modern glaciers are preferentially located on southeastern slopes (Meier et al., 2018), and are the ice relics of more extensive ice coverage in the past. PATICE ice reconstructions show the changing distribution of ice from the Last Glacial Maximum to the recent past with reconstructions at 0.2, 5, 10 and $13 \mathrm{ka}$ (Davies et al., 2020).

Together, these maps are used to assign a numerical value to the presence of ice in catchments during the delta development period. An ice factor value of zero $(X=0)$ is assigned to cases where no ice was 
present in the last $13 \mathrm{ka}$. Correspondingly, a value of one $(X=1)$, represents ice within the catchment throughout that period and is evaluated based on modern glaciers in the basin. To designate sites that have ice present for only a portion of the time, we assigned a value of 0.5 . In cases where the ice mapping is close to the drainage divide, we assess if this cross-over into an adjacent basins is due to the coarse scale of the ice reconstructions or geospatial registration misalignment.

\section{Results}

\subsection{Catchment and delta size}

The scale of Lake General Carrera fan deposits and their catchments span a wide area range (Table 4; Fig. 5A). The basin area associated with the studied deltas ranges over a factor of nearly one hundred, from 18 to $2407 \mathrm{~km}^{2}$. The largest catchments are on either side of the lake, with Río Ibáñez and Chile Chico (Río Jeinimeni) to the east and Río Murta to the west.

TABLE 4. DELTA MEASUREMENTS: LOCATION, FAN SIZE AND CATCHMENT CHARACTERISTICS.

\begin{tabular}{|c|c|c|c|c|c|c|c|c|c|}
\hline \multirow[b]{2}{*}{ Name } & \multirow[b]{2}{*}{$\begin{array}{c}\text { Fan } \\
\#\end{array}$} & & & \multicolumn{3}{|c|}{ Fan length } & \multicolumn{2}{|c|}{ Area } & \multirow[b]{2}{*}{$A_{f} / A_{d}$} \\
\hline & & \multicolumn{2}{|c|}{ Coordinates } & $\begin{array}{r}\text { T1 } \\
\text { km }\end{array}$ & $\begin{array}{l}\text { T2+ } \\
\text { km }\end{array}$ & $\begin{array}{c}\text { Total } \\
\text { km }\end{array}$ & $\begin{array}{l}\text { Fan } \\
\mathbf{k m}^{2}\end{array}$ & $\begin{array}{c}\text { Basin } \\
\mathbf{k m}^{2}\end{array}$ & \\
\hline Dunas & 1 & 46.797 & 72.576 & 0.95 & 4.1 & 5.11 & 11 & 145 & 0.08 \\
\hline Maitenes & 2 & 46.771 & 72.495 & 1.85 & 7.2 & 9.05 & 40 & 425 & 0.09 \\
\hline Fachinal & 3 & 46.588 & 72.225 & 1.8 & 4 & 5.8 & 20 & 255 & 0.08 \\
\hline Santa Clara & 4 & 46.585 & 72.141 & 0.23 & 3.6 & 3.83 & 2.5 & 18 & 0.14 \\
\hline Chile Chico & 5 & 46.636 & 71.645 & 3.3 & 8.6 & 11.9 & 65 & 1,395 & 0.05 \\
\hline Moncada & 6 & 46.297 & 71.779 & 0.82 & 4.09 & 4.91 & 4 & 45 & 0.09 \\
\hline Lechoso & 7 & 46.248 & 71.927 & 1.3 & 3.8 & 5.1 & 5 & 85 & 0.06 \\
\hline Ibáñez & 8 & 46.255 & 72.032 & 5.05 & 4.5 & 9.55 & 16 & 2,407 & 0.01 \\
\hline Avellano & 9 & 46.499 & 72.176 & 1.45 & 4.09 & 5.54 & 19 & 312 & 0.06 \\
\hline Muller & 10 & 46.599 & 72.5 & 0.3 & 2.3 & 2.6 & 2.6 & 23 & 0.11 \\
\hline Sánchez-east & 11 & 46.586 & 72.576 & 0.52 & 1.65 & 2.17 & 1.5 & 19 & 0.08 \\
\hline Sánchez-west & 12 & 46.581 & 72.599 & 0.85 & 2.3 & 3.15 & 2.5 & 41 & 0.06 \\
\hline Murta & 13 & 46.455 & 72.673 & 2.5 & 6 & 8.5 & 27 & 896 & 0.03 \\
\hline Estero Pérez & 14 & 46.536 & 72.725 & 1.1 & 0.7 & 1.8 & 4 & 47 & 0.09 \\
\hline Río el Canal & 15 & 46.794 & 72.813 & 1.5 & 1.3 & 2.8 & 4 & 105 & 0.04 \\
\hline
\end{tabular}

Fan\# as in figure 2.

$\mathrm{T} 1$ and $\mathrm{T} 2+$ refer to terrace level with the modern (active) delta designated

$\mathrm{T} 1$, and older terraces are grouped together for $\mathrm{T} 2+$.

${ }^{3} \mathrm{~A} f / \mathrm{A} d$ is the dimensionless ratio of fan area to drainage area.
Delta size can be described by several measurements, including planview scale (length and area), as well as the three-dimensional volume. In this section we exclude scale values for two of the largest deltas. Measurements for Río Murta and Río Ibáñez are highly uncertain because deposit dimensions are poorly constrained within the wide river valleys, especially for the older perched deltas; nevertheless, estimated values for both sites are reported in table 4.

Active deltas (T1) are between 0.2 and $3.3 \mathrm{~km}$ long, but most are less than $2 \mathrm{~km}$ in length (Fig. 4C). In terms of spatial extent, the area of active deltas varies between 0.3 and $36 \mathrm{~km}^{2}$. One-third of active deltas cover a surface area of $<2 \mathrm{~km}^{2}$.

The total radial length of each delta sequence ranges from 1.8 to $11.9 \mathrm{~km}$ (Fig. 4C). Delta length increases eastward across the lake, with considerable scatter in the data. One of the largest delta complexes at Lake General Carrera is Chile Chico with a radial length of almost $12 \mathrm{~km}$, and it extends across an area of $65 \mathrm{~km}^{2}$. Delta complexes cover areas from 1.5 to $65 \mathrm{~km}^{2}$.

Estimated active delta volume $\left(V_{l}\right)$ based on measured dimensions ranged from 0.001 to $\sim 0.2 \mathrm{~km}^{3}$ (Table 5). This computed delta volume is based on the exposed deposit, and would be larger if the subaqueous deposit were included. Bell (2009) estimated that the subaerial deposit is at most onethird of the total delta volume, comprised of braided river deposits $(20 \%)$ and beach deposits $(10 \%)$; the bulk of the transported sediment $(70 \%)$ is deposited underwater. This relationship is visible in vertical exposures where topsets are a minor component of the perched delta and the majority of the eroded delta front is foresets (see below section 4.3). Delta volume based on extrapolated dimensions $\left(V_{2}\right)$ ranges from 0.003 to $\sim 0.6 \mathrm{~km}^{3}$ (Table 5).

\subsection{Progradation rate}

We estimate the progradation rate for the delta sequence by subdividing them into ancient and active deltas. Bell (2009) estimates the formation period for ancient deltas (T2 and older) spanned a period of $<5 \mathrm{ka}$ based on radiometric dates reported in Glasser et al. (2004), Turner et al. (2005), and Douglass et al. (2005). Based on this age constraint, the minimum progradation rates for ancient deltas ranges between 0.1-1.7 m/yr (Table 5). In contrast, 

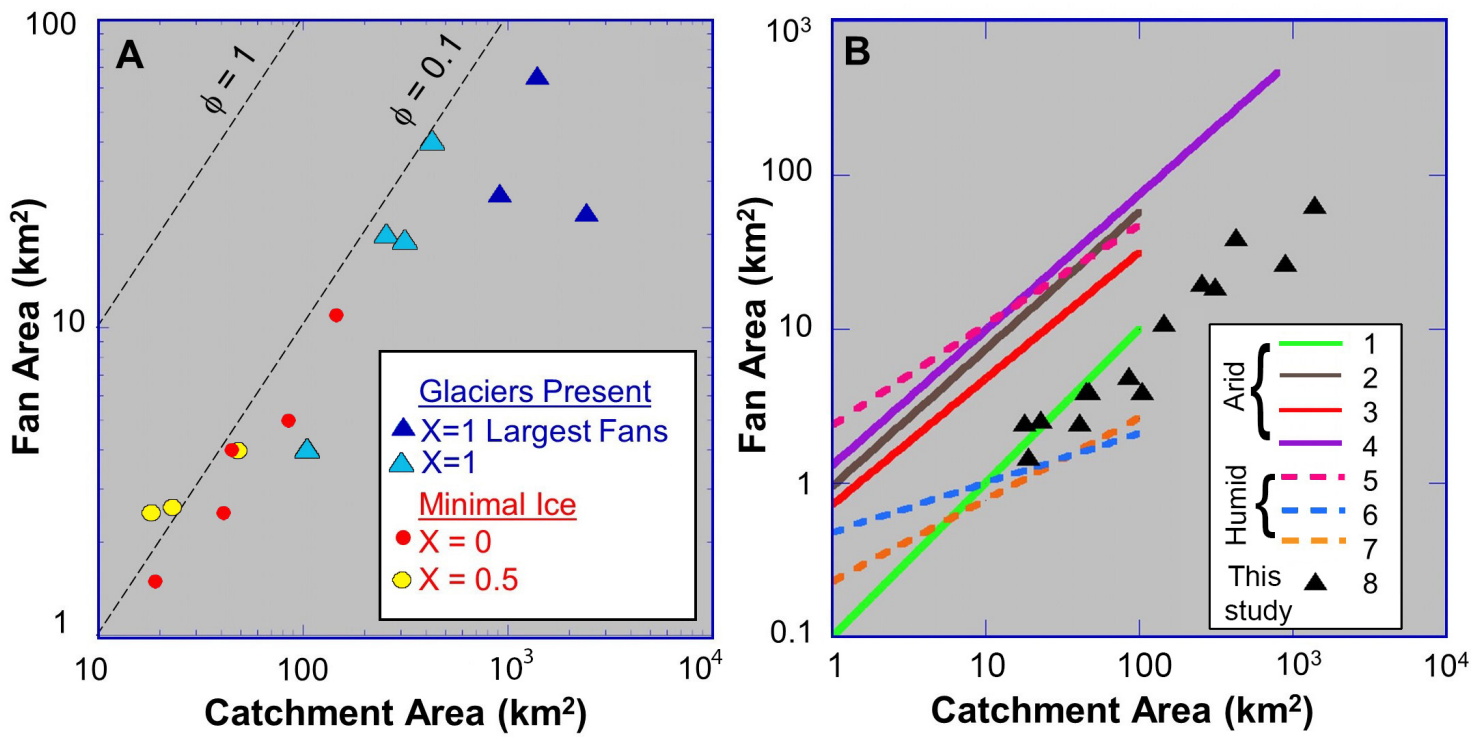

FIG. 5. Relationship between fan area and catchment area. A. Data for Lake General Carrera deltas is color coded by the ice factor, $X$, a measure of glacial retention in the catchment. Power law regression fit to data (omitting Ibánez): $A_{f}=0.16\left(A_{d}\right) \mathrm{R}^{2}=0.93$. B. Comparison of Lake General Carrera deltas (green triangles, 8, this study) to fan-catchment trendlines from published studies: 1. east side of Death Valley, CA and NV (Denny, 1965); 2. west side of Death Valley, CA (Hooke and Rohrer, 1977); 3. Almeria, Spain (Harvey, 1989); 4. Fresno, CA (Bull, 1964); 5. Aklavik, Northwest Territories, Canada (Master's thesis by A. B. Keeble reported in Allen and Hovius, 1998); 6. Banff, Canada (Kostaschuk et al., 1986); 7. Dellwood, CA (Mills, 1982). Arid environments are solid lines and humid environments are dashed lines.

TABLE 5. PROGRADATION RATE AND INTERMITTENCY FACTOR.

\begin{tabular}{|c|c|c|c|c|c|c|c|c|c|c|}
\hline \multirow{3}{*}{ Location } & \multirow{3}{*}{$\begin{array}{c}\text { Fan } \\
\#\end{array}$} & \multicolumn{3}{|c|}{ Progradation Rate } & \multicolumn{2}{|c|}{ Assumed } & \multicolumn{2}{|c|}{ T1 Volume } & \multirow{2}{*}{\multicolumn{2}{|c|}{$\begin{array}{c}\text { Intermittency } \\
I_{f}\left(10^{-4}\right)\end{array}$}} \\
\hline & & T1 & $\mathbf{T} 2+$ & Total & $Q$ & $Q_{\text {sed bf }}$ & $V_{1}$ & $V_{2}$ & & \\
\hline & & $\mathbf{m} / \mathbf{y r}$ & $\mathbf{m} / \mathbf{y r}$ & $\mathbf{m} / \mathbf{y r}$ & $\mathbf{m}^{3} / \mathbf{s}$ & $\mathbf{m}^{3} / \mathbf{s}$ & $\mathbf{k m}^{3}$ & $\mathbf{k m}^{3}$ & $\left(V_{1}\right)$ & $\left(V_{2}\right)$ \\
\hline Dunas & 1 & 0.15 & 0.82 & 0.45 & 425 & 0.425 & 0.008 & 0.027 & 0.96 & 3.2 \\
\hline Maitenes & 2 & 0.3 & 1.44 & 0.81 & 425 & 0.425 & 0.036 & 0.12 & 4.3 & 14 \\
\hline Fachinal & 3 & 0.29 & 0.8 & 0.52 & 425 & 0.425 & 0.025 & 0.082 & 3.0 & 9.9 \\
\hline Santa Clara & 4 & 0.04 & 0.72 & 0.34 & 425 & 0.425 & 0.001 & 0.004 & 0.1 & 0.4 \\
\hline Chile Chico & 5 & 0.53 & 1.72 & 1.06 & 260 & 0.26 & 0.175 & 0.583 & 34 & 115 \\
\hline Moncada & 6 & 0.13 & 0.82 & 0.44 & 275 & 0.275 & 0.01 & 0.035 & 1.9 & 6.5 \\
\hline Lechoso & 7 & 0.21 & 0.76 & 0.46 & 275 & 0.275 & 0.003 & 0.009 & 0.5 & 1.6 \\
\hline Ibáñez & 8 & 0.81 & 0.9 & 0.85 & 650 & 0.65 & - & - & - & - \\
\hline Avellano & 9 & 0.23 & 0.82 & 0.49 & 100 & 0.1 & 0.021 & 0.069 & 11 & 35 \\
\hline Muller & 10 & 0.05 & 0.46 & 0.23 & 100 & 0.1 & 0.001 & 0.003 & 0.5 & 1.7 \\
\hline Sánchez-east & 11 & 0.08 & 0.33 & 0.19 & 100 & 0.1 & 0.003 & 0.009 & 1.3 & 4.4 \\
\hline Sánchez-west & 12 & 0.14 & 0.46 & 0.28 & 100 & 0.1 & 0.006 & 0.021 & 3.2 & 11 \\
\hline Murta & 13 & 0.4 & 1.2 & 0.76 & 700 & 0.7 & - & - & - & - \\
\hline Estero Pérez & 14 & 0.18 & 0.14 & 0.16 & 100 & 0.1 & 0.016 & 0.053 & 8.1 & 27 \\
\hline Río el Canal & 15 & 0.24 & 0.26 & 0.25 & 600 & 0.6 & 0.015 & 0.049 & 1.2 & 4.2 \\
\hline
\end{tabular}

Fan\# as in figure 2 .

$\mathrm{T} 1$ and $\mathrm{T} 2+$ refer to terrace level with the modern (active) delta designated $\mathrm{T} 1$, and older terraces are grouped together for $\mathrm{T} 2+$.

$Q$ is the flood discharge. See section IV.4 for details on assumed values.

$Q_{\text {sed }}$ is the bankfull sediment discharge.

$V$ is the exposed active (T1) fan volume.

$V_{2}$ is the extrapolated active (T1) fan volume accounting for subaqueous component of deposit.

$I_{f}$ is the dimensionless intermittency factor determined as the ratio of sediment deposition time to the total time. 
the $\sim 6.2 \mathrm{ka}$ development period for the active deltas (Turner et al., 2005) corresponds to a progradation rate between $0.04-0.5 \mathrm{~m} / \mathrm{yr}$. Every site had a decrease in the delta growth rate of $>0.1 \mathrm{~m} / \mathrm{yr}$ except for the two smallest deltas (Estero Pérez and Río el Canal) which had minimal change over time. The largest disparity in progradation rates between these two periods is found at Río Maitenes and Chile Chico which had a rate decrease in excess of $1 \mathrm{~m} / \mathrm{yr}$. This slowing growth rate at multiple delta sites may be partially due to higher sediment supply (unconsolidated glacial sediment) in the past that was reduced by increasing vegetation cover as the climate warmed (Bell, 2009).

\subsection{Sedimentology}

Sedimentology observations are concentrated on the southern margin of Lake General Carrera at the active and lower terrace levels due to road access. Vertical exposures of the T2 and T3 deltas show a) topsets in the upper 10-30 m of the terrace and, b) steeply dipping, planar cross beds (foresets) in cliff-faces approximately perpendicular to the lake shoreline (Fig. 6).

Most of the grain size measurements are at $\mathrm{T} 2$ locations, with exposures of both the delta top and delta flank. Vegetation cover obscured grain size data

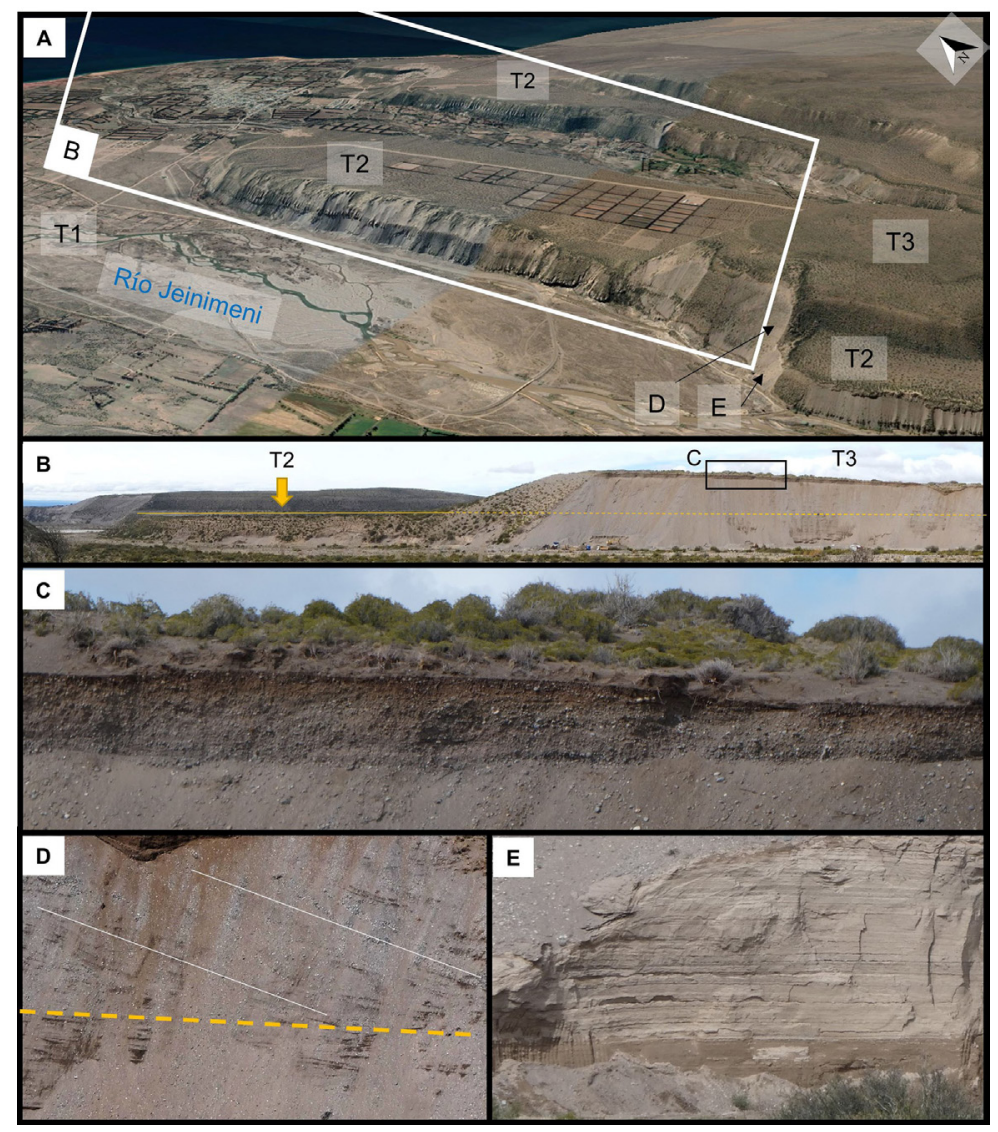

FIG. 6. Vertical exposure of abandoned deltas illustrate the three-dimensional architecture. A. Satellite oblique perspective view of Chile Chico delta sequence from Google Earth with active delta (T1) and two older deltas (T2 and T3) labelled. B. Photo of cliff exposure parallel to delta progradation direction of two delta terraces (white box in A). The younger T2 surface is projected across the exposed T3 terrace (orange solid to dashed line), and corresponds with planar bedding (shown in D). The topsets are a minor component of the delta volume $(<10 \%)$, which is dominantly foresets. C. Delta T3 topsets are planar bedded and include cobble-size clasts (white dots). D. Beneath the T3 topsets are steeply dipping cross-beds (white lines) and the extension of T2 topsets in horizontal layers (orange dashed line). E. Sequence of planar beds ( $\sim 10 \mathrm{~m}$ thick) beneath the T2 delta top appear to lack coarse clasts. These could be muddy river overbank or lacustrine deposits. Photos are of site located near $46.6054^{\circ} \mathrm{S}, 71.686428^{\circ} \mathrm{W}$. 
at older delta terraces. Grain size data for Dunas, Maitenes, Fachinal, and Chile Chico deltas is reported in table 6. Summarizing grain size observations from multiple sites, the coarsest fraction within foresets is cobble $(10-25 \mathrm{~cm})$, whereas larger boulder clasts $(70-100 \mathrm{~cm})$ are present in isolated topset layers (Fig. 7). At Fachinal, three beds had boulders within a $\sim 15 \mathrm{~m}$ topset section (Fig. 8). The Fachinal exposure is the best example we observed, although similar associations were observed elsewhere. For example, four boulder-rich layers are present in the $20 \mathrm{~m}$ topset section at Dunas (Fig. 7C). Bell (2009) mentions the presence of boulders at Río Dunas, but these large clasts are not incorporated into his facies descriptions. The occurrence of meter-size boulders in individual layers is consistent with discreet large flood events, while typical, more frequent flood events transport cobbles and gravels that constitute the bulk of the exposed delta volume. Some boulders are clearly glacially derived. Boulders $(\sim 3 \mathrm{~m})$ on the surface at Fachinal are associated with the glacial moraine deposits (Douglass et al., 2005; Bourgois et al., 2016).

Along the lakeshore, modern beach bar deposits are present in concave embayments (Fig. 9A). Beach gravels are well sorted with coarser pebbles on bars and finer pebbles on the slopes of the shoreline bars figure 9B-C. Clasts on the beach are smaller than those observed on the delta tops.

A similar geomorphic expression to the modern beach bars is present on some perched delta fronts. Lateral terraces near Río Dunas are shown in figure 3 , but thick vegetative cover prevented grain size measurements. Ridge-swale topography is present above T3 at Río Maitenes (Fig. 9B). Grain size measurements at this site are coarser on the ridges $\left(\mathrm{D}_{84}=9 \mathrm{~cm}\right)$ and finer on the lowlands $\left(\mathrm{D}_{84}=2 \mathrm{~cm}\right)$, a pattern that matches the modern beach bars (Fig. 9D-E). We interpret these undulations as shorelines formed by storm-driven wave erosion.

\subsection{Discharge}

The hydrologic regime of Patagonian rivers is governed by seasonal floods, storm events and rare, catastrophic ice-melt release events (Dussaillant et al., 2012). These different flow types are evident in the surface morphology on the modern delta (Fig. 10). The relative role of each of these hydrologic drivers varies by river.

TABLE 6. GRAIN SIZE DATA.

\begin{tabular}{|c|c|c|c|c|c|c|}
\hline $\begin{array}{l}\text { Latitude } \\
\left({ }^{\circ} \mathrm{S}\right)\end{array}$ & $\begin{array}{c}\text { Longitude } \\
\left({ }^{\circ} \mathbf{W}\right)\end{array}$ & $\begin{array}{c}D_{84} \\
(\mathrm{~cm})\end{array}$ & Exposure & $\begin{array}{l}\text { Depositional } \\
\text { setting }\end{array}$ & Terrace level & River \\
\hline 46.766 & 72.594 & $\sim 50^{\mathrm{a}}$ & Modern River & River & $\mathrm{T} 1$ & Dunas \\
\hline 46.779 & 72.612 & 5 & Modern Beach & Beach Bars & $\mathrm{T} 1$ & Dunas \\
\hline 46.763 & 72.470 & 9 & Delta Top & Beach Bars & $\mathrm{T} 3$ & Maitenes \\
\hline 46.786 & 72.575 & 10 & Delta Top & Beach Bars & $\mathrm{T} 3$ & Dunas \\
\hline 46.764 & 72.586 & 25 & Delta Top & Topset & $\mathrm{T} 2$ & Dunas \\
\hline 46.779 & 72.607 & 10 & Delta Top & Topset & $\mathrm{T} 2$ & Dunas \\
\hline 46.771 & 72.599 & 25 & Delta Top & Topset & $\mathrm{T} 2$ & Dunas \\
\hline 46.771 & 72.599 & 15 & Delta Top & Topset & $\mathrm{T} 2$ & Maitenes \\
\hline 46.752 & 72.555 & 5 & Delta Top & Topset & $\mathrm{T} 2$ & Maitenes \\
\hline 46.775 & 72.509 & $10^{\mathrm{b}}$ & Delta Top & Topset & $\mathrm{T} 3$ & Maitenes \\
\hline 46.769 & 72.603 & 20 & Delta Front & Foreset & $\mathrm{T} 2$ & Dunas \\
\hline 46.771 & 72.596 & $\sim 15^{\mathrm{a}}$ & Delta Front & Foreset & $\mathrm{T} 2$ & Dunas \\
\hline 46.574 & 72.220 & $\sim 15^{\mathrm{b}}$ & Delta Side & Foreset & $\mathrm{T} 2$ & Fachinal \\
\hline 46.605 & 71.686 & $\sim 15^{\mathrm{b}}$ & Delta Side & Foreset & $\mathrm{T} 3$ & Jeinimeni \\
\hline 46.768 & 72.599 & $\sim 70^{\mathrm{a}}$ & Delta Front & Topset & $\mathrm{T} 2$ & Dunas \\
\hline 46.771 & 72.596 & $\sim 100^{\mathrm{a}}$ & Delta Side & Topset & $\mathrm{T} 2$ & Dunas \\
\hline 46.574 & 72.220 & $\sim 90^{\mathrm{b}}$ & Delta Side & Topset & $\mathrm{T} 2$ & Fachinal \\
\hline 46.605 & 71.686 & $\sim 80^{\mathrm{b}}$ & Delta Side & Topset & $\mathrm{T} 3$ & Jeinimeni \\
\hline$\sim 46.576$ & $\sim 72.196$ & $\sim 300^{\mathrm{c}}$ & Delta Top & Glacial moraine & $\mathrm{T} 2$ & Fachinal \\
\hline
\end{tabular}

${ }^{a}$ Grain size measurement made from afar (photographed from a distance or drone image) and coarsest clasts reported.

${ }^{\mathrm{b}}$ Estimated $\mathrm{D}_{90}$ value because insufficient exposure to conduct full pebble count.

${ }^{\mathrm{c}}$ Boulders associated with glacial moraine (Douglas et al., 2005; Bourgois et al., 2016) 


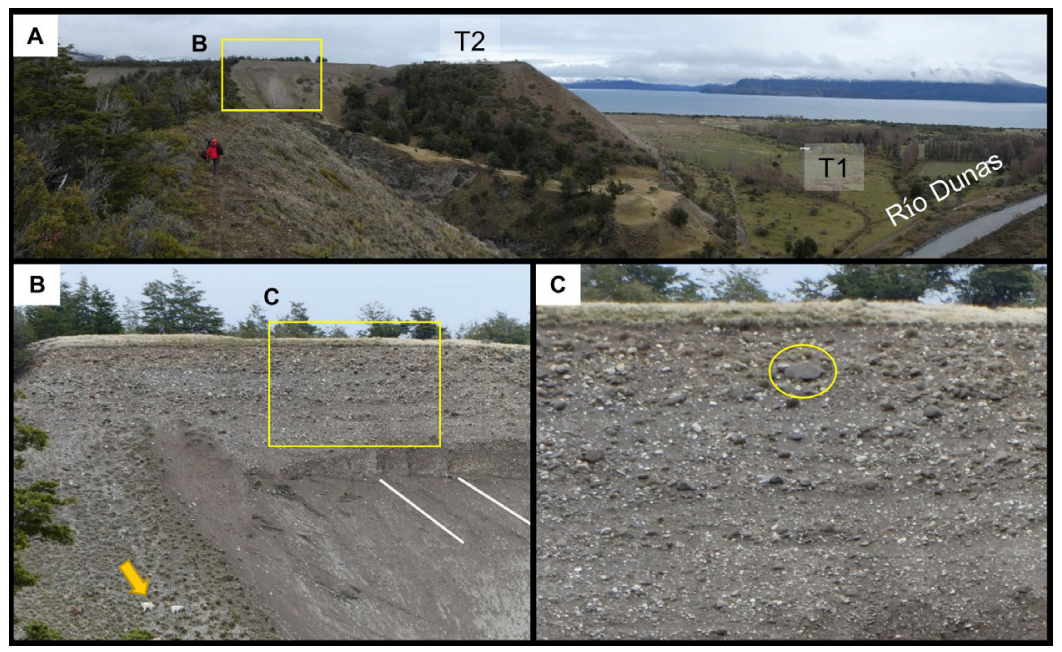

FIG. 7. Cliff exposure at Río Dunas illustrates grain size distribution associated with the delta sedimentary architecture. A. Context photo of T2 outcrop, aligned parallel to Río Dunas. B. Outcrop exhibits planar bedded topsets, and lower down are inclined foresets (white lines). Sheep are near orange arrow. C. Isolated layers in the topsets have boulders (clast marked by yellow oval is $1.2 \mathrm{~m}$ across). Outcrop is near $46.7712^{\circ} \mathrm{S}, 72.5962^{\circ} \mathrm{W}$.

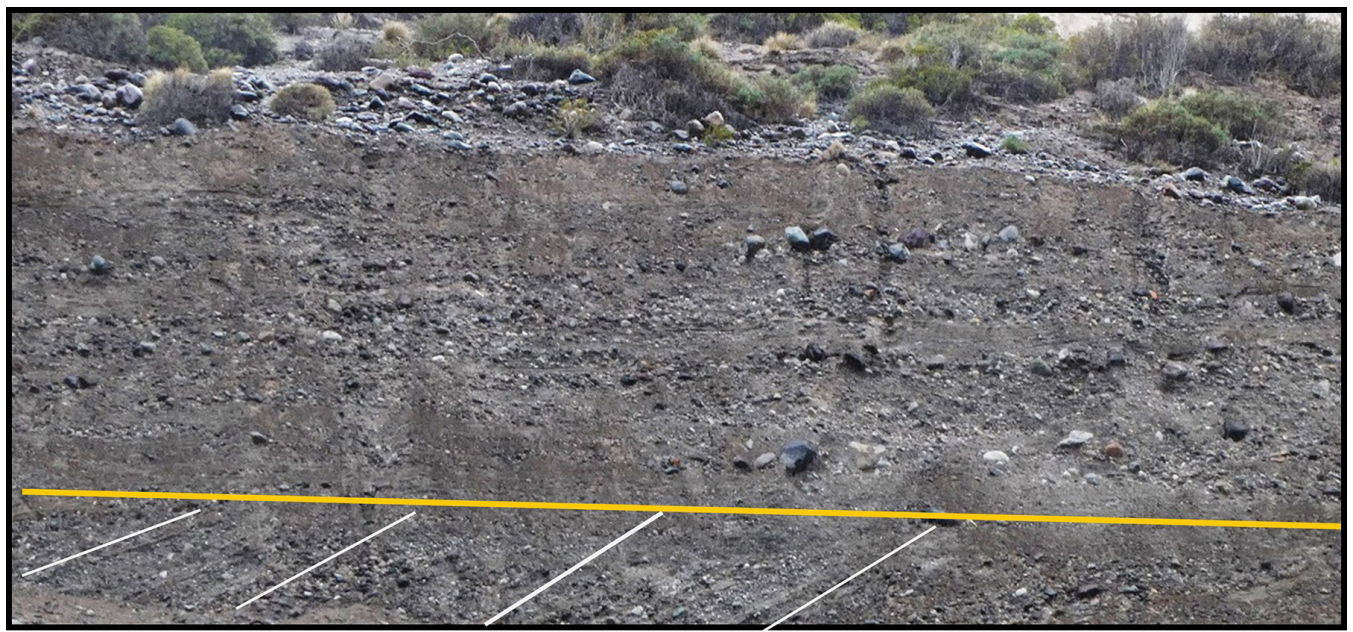

FIG. 8. Boulders are preferentially found in topsets in this cliff exposure at Fachinal. The T2 topsets (lower bound marked by orange line) have isolated horizontal layers with meter-size boulders, whereas cobbles are the largest clasts in the forsests (white guidelines). Photos are of site located near $46.574088^{\circ} \mathrm{S}, 72.220351^{\circ} \mathrm{W}$.

The available river gauge data is associated with the larger rivers feeding Lake General Carrera. For comparison to this dataset, we estimate various flow discharge for Río Dunas and Río Maitenes using the equations in section 3.3 and incorporating grain size data from table 6 . We estimate the scale of typical river flows as well as various flooding events. These two sites have comparably sized input parameters, and therefore we report their derived discharges together.
With a perennial flow width of $30 \mathrm{~m}$, the hydraulic geometry relationship of equation 2 yields a $Q_{w}$ discharge estimate of $\sim 60 \mathrm{~m}^{3} / \mathrm{s}$. To estimate the threshold discharge $\left(Q_{T}\right)$, the change in stream slope as it enters the lake is evaluated (Table 6). The lower river reaches have a gradient of $1.4^{\circ}$ that decreases to $0.6^{\circ}$ on the modern delta plain. For this gradient range, the bankfull discharge to mobilize cobble size clasts $(0.25 \mathrm{~m})$ is $25-60 \mathrm{~m}^{3} / \mathrm{s}$ 


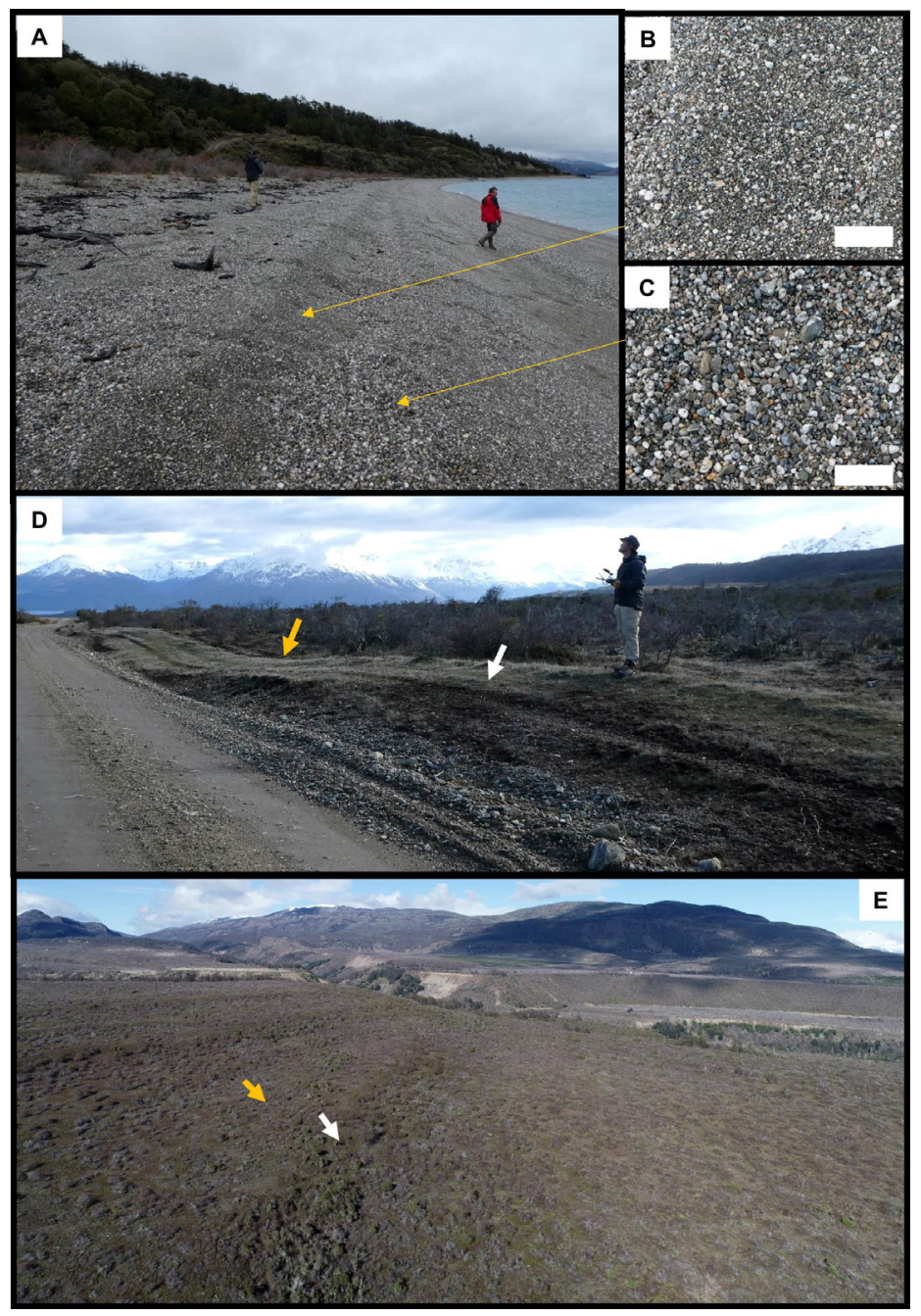

FIG. 9. Illustrations of modern and ancient shorelines. A. Along shoreline view of well sorted pebbles in beach bars. The coarser fraction is concentrated on the ridges by wave-action (B) and finer clasts are on the slopes (C). Ten centimeter scale bar for panels B and C. D. Ridge and swale topography (white and orange arrows, respectively) above the T3 delta at Río Maitenes. E. Oblique aerial perspective view along the relict shoreline features.

for the modern river width. Together, these two approaches suggest baseflow of a few tens of cubic meters per second.

The magnitude of flooding events is constrained by the size of active (unvegetated) tracts and location of boulders. For example, a small boulder $(0.5 \mathrm{~m})$ located in the modern confined river at Dunas requires a threshold discharge of $\sim 180 \mathrm{~m}^{3} / \mathrm{s}$ to mobilize it across the delta plain. A similar magnitude flood could form the narrowest active tract $(60 \mathrm{~m})$ based on hydraulic geometry $\left(Q_{w}=179 \mathrm{~m}^{3} / \mathrm{s}\right)$. This scale of event likely occurs a few times each year.
Bankfull floods to carve the wider unvegetated flow paths $(130$ and $250 \mathrm{~m})$ would range from $Q_{w}=$ 650 to $\sim 2000 \mathrm{~m}^{3} / \mathrm{s}$. For the case corresponding to the $130 \mathrm{~m}$ flood width, the threshold discharge would need to exceed $\sim 740 \mathrm{~m}^{3} / \mathrm{s}$ or $\sim 2170 \mathrm{~m}^{3} / \mathrm{s}$, depending on river gradient. Here we adopt a grain size of $1 \mathrm{~m}$, matching the largest size observed in the topsets of ancient deltas at Dunas, Maitenes and Fachinal (Table 6). Threshold discharge for the largest flow path $(250 \mathrm{~m})$ ranges from $\sim 1400-4200 \mathrm{~m}^{3} / \mathrm{s}$ for the gradient range. These extreme flow conditions are associated with rare ice-melt release events. 


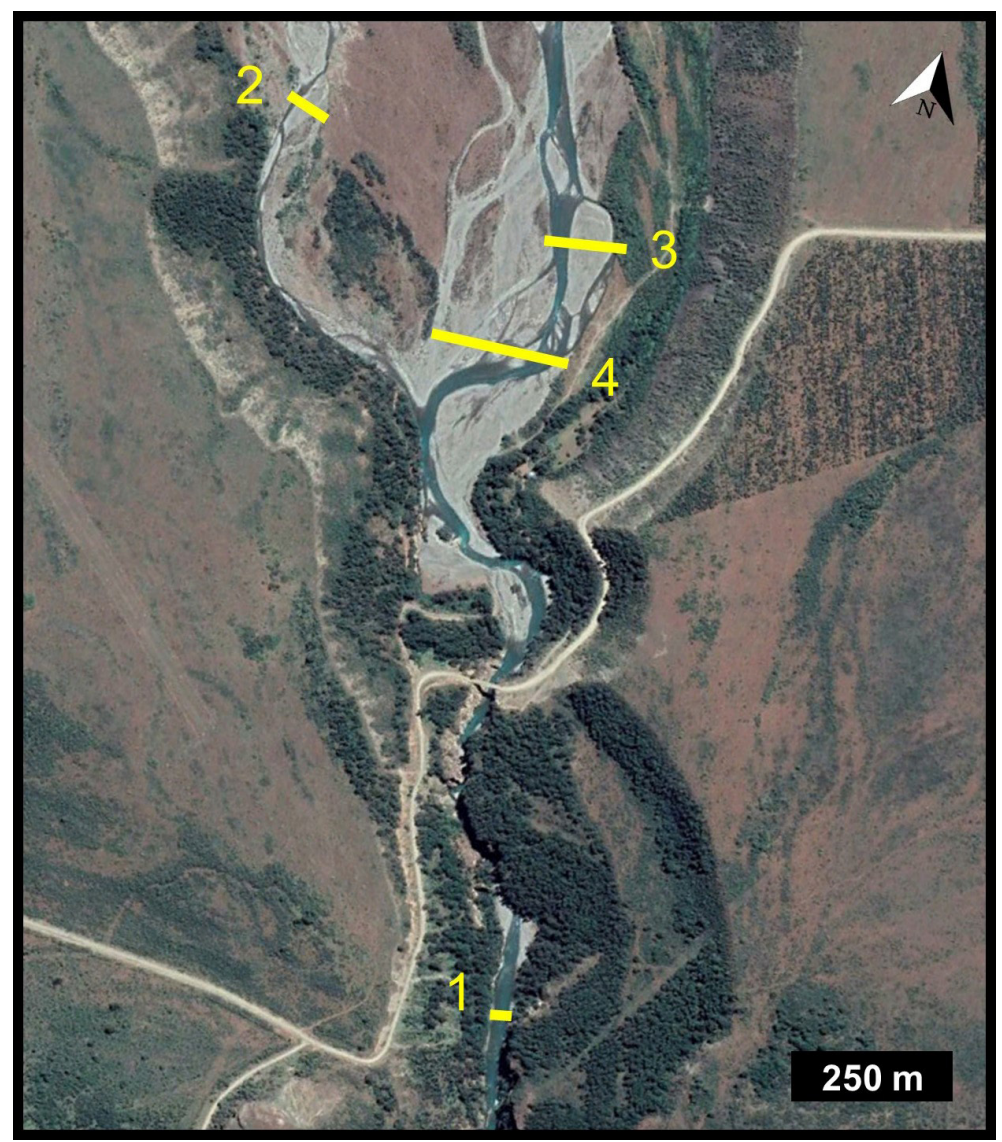

FIG. 10. The widths of different flood events are preserved near the apex of the modern delta at Río Maitenes. Representative width measurement locations are marked by numbers: $\mathbf{1}$. river width is $30 \mathrm{~m}, \mathbf{2}$. small active tract associated with seasonal or storm floods $(60 \mathrm{~m})$, and two-generations of superposing flood swaths at 3. and 4. (130 m and $250 \mathrm{~m}$, respectively) are associated with rare, high magnitude flow events.

\subsection{Intermittency factor}

We compute the intermittency factor for the youngest deltas (T1) where volume estimate and river discharge are better constrained than for ancient deltas (Table 5). For the youngest deltas, we estimate the range in the intermittency factor is from $3 \times 10^{-3}$ to $1 \times 10^{-5}$ based on the exposed fan volume $\left(V_{1}\right)$ and assuming the maximum temporal formation period of $6.2 \mathrm{ka}$ (Fig. 11A). Accounting for the distribution of depositional facies (see section V.1), the extrapolated total T1 delta volume $\left(V_{2}\right)$, and by extension the corresponding intermittency factor, increase by a factor of 3.3: $I_{\mathrm{f}}=1 \times 10^{-2}$ to $4 \times 10^{-5}$ (Fig. 11A, Table 5). We consider the extrapolated volume more representative of the total deposit volume, but due to the uncertainty we report estimates for intermittency factor derived from both volume estimates.

Overall, our adopted input values to compute the intermittency factor yield values near the upper plausible limit. The development period could have been shorter, but is unlikely to increase the computed intermittency by more than a factor of 2 . The largest parameter uncertainty is associated with the sediment discharge, where a larger value would decrease the intermittency factor. Multiple approaches have been proposed to estimate the sediment discharge, but there is a paucity of accurate field data and no universal approach has been formulated (Gray and Simões, 2008). Floods can transport sediment concentrations up to $20 \%$ by volume (Costa, 1988). Thus, more realistic sediment discharge values would decrease the intermittency factor conceivably by up to 2 orders of magnitude. 


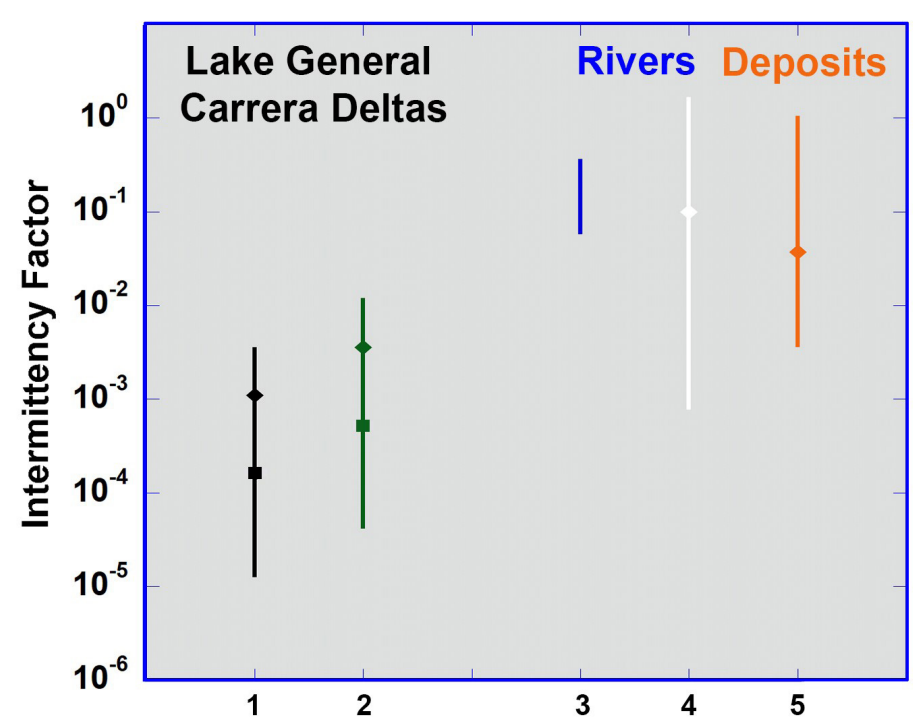

FIG. 11. Comparison of intermittency factor values derived in this study to values for other sites. The computed intermittency factor is displayed separately based on measured delta volume (black line) and extrapolated delta volume (green line). For each case, the average intermittency factor is marked by ice factor ( $X=1$ diamonds; $X=0$ squares). The range in published intermittency factors is shown at right with measured values for rivers (dark blue line) and computed values from stream gauge data (white line) and sedimentary deposits (orange line; Hayden et al., 2021; see text for details). All derived intermittency values for Lake General Carrera deltas are significantly below the median intermittency value of modern rivers ( 0.10 marked by white diamond) and sedimentary deposits ( 0.04 marked by orange diamond; Hayden et al., 2021)

\subsection{Ice coverage within the catchment}

For the last $13 \mathrm{ka}$, nearly half of the catchments (7/15) had glaciers continuously present $(X=1$; Table 7). Throughout this time period, glaciers are absent $(X=0)$ in five catchments. Ice reconstructions from $0.2 \mathrm{ka}$ and older show glaciers in the catchments of Muller and Santa Clara (Fig. 2). For Estero Perez, ice has not been present for several thousand year $(\sim 10 \mathrm{ka})$. We group these later two ice factors $(X=0$ and 0.5$)$ together, and classify them as minimal ice presence within the catchment.

As an illustration, figure 12 shows the ice distribution over time for the adjacent catchments at Río Maitenes and Río Dunas. These two neighboring delta terrace sequences are significantly different in scale: double the length and four-fold difference in area, with Río Maitenes as the larger delta. In the ice reconstructions, the glacier size and extent increases over time for the Río Maitenes catchment, whereas there is no ice in the smaller Río Dunas catchment for the last $13 \mathrm{ka}$. Maximum elevation in the Río Dunas catchment is $\sim 200 \mathrm{~m}$ lower elevation than peak heights within the Río Maitenes catchment (Fig. 2), which may account for less ice accumulation in the
TABLE 7. ICE IN CATCHMENT.

\begin{tabular}{|c|c|c|c|c|c|c|}
\hline & \multirow{2}{*}{$\begin{array}{c}\text { Ice } \\
\text { Factor } \\
X\end{array}$} & \multirow{2}{*}{$\begin{array}{l}\text { Glaciers } \\
\text { Modern }\end{array}$} & \multicolumn{4}{|c|}{$\begin{array}{l}\text { PATICE Ice } \\
\text { reconstructions }\end{array}$} \\
\hline & & & $\begin{array}{l}0.2 \\
\text { ka }\end{array}$ & $\begin{array}{c}5 \\
\mathbf{k a}\end{array}$ & $\begin{array}{l}10 \\
\mathbf{k a}\end{array}$ & $13 \mathrm{ka}$ \\
\hline Dunas & 0 & $\mathrm{~N}$ & $\mathrm{~N}$ & $\mathrm{~N}$ & $\mathrm{~N}$ & $\mathrm{~N}$ \\
\hline Moncada & 0 & $\mathrm{~N}$ & $\mathrm{~N}$ & $\mathrm{~N}$ & $\mathrm{~N}$ & $\mathrm{~N}$ \\
\hline Lechoso & 0 & $\mathrm{~N}$ & $\mathrm{~N}$ & $\mathrm{~N}$ & $\mathrm{~N}$ & $\mathrm{~N}$ \\
\hline Sánchez-east & 0 & $\mathrm{~N}$ & $\mathrm{~N}$ & $\mathrm{~N}$ & $\mathrm{~N}$ & $\mathrm{~N}$ \\
\hline Sánchez-west & 0 & $\mathrm{~N}$ & $\mathrm{~N}$ & $\mathrm{~N}$ & $\mathrm{~N}$ & $\mathrm{~N}$ \\
\hline Santa Clara & 0.5 & $\mathrm{~N}$ & Y & $\mathrm{Y}$ & $\mathrm{Y}$ & Y \\
\hline Muller & 0.5 & $\mathrm{~N}$ & Y & Y & $\mathrm{Y}$ & Y \\
\hline Estero Pérez & 0.5 & $\mathrm{~N}$ & $\mathrm{~N}$ & $\mathrm{~N}$ & Y & Y \\
\hline Maitenes & 1 & Y & Y & $\mathrm{Y}$ & $\mathrm{Y}$ & Y \\
\hline Fachinal & 1 & Y & $\mathrm{Y}$ & $\mathrm{Y}$ & $\mathrm{Y}$ & $\mathrm{Y}$ \\
\hline Avellano & 1 & Y & Y & $\mathrm{Y}$ & Y & Y \\
\hline Chile Chico & 1 & Y & Y & $\mathrm{Y}$ & $\mathrm{Y}$ & $\mathrm{Y}$ \\
\hline Ibáñez & 1 & Y & Y & $\mathrm{Y}$ & Y & Y \\
\hline Murta & 1 & Y & Y & $\mathrm{Y}$ & $\mathrm{Y}$ & Y \\
\hline Río el Canal & 1 & Y & Y & $\mathrm{Y}$ & $\mathrm{Y}$ & $\mathrm{Y}$ \\
\hline
\end{tabular}

*Dunas, Maitenes, Fachinal, and Santa Clara share the same sub-basin, but not the same ice factor $X$ (assessment of ice presence in catchment over time). $\mathrm{N}=$ no ice present. $\mathrm{Y}=$ ice present. 


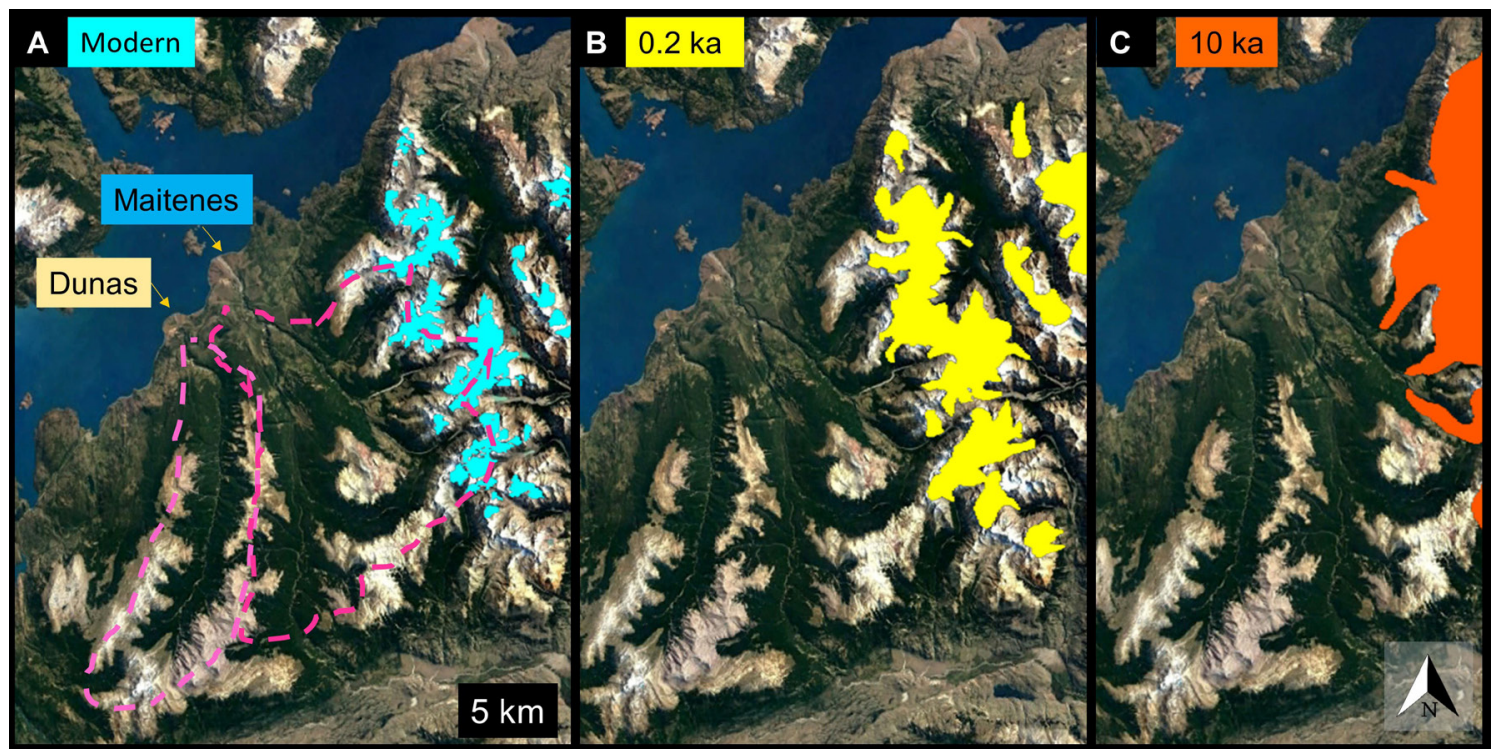

FIG. 12. Glacier distribution and ice reconstructions (PATICE) reported in Davies et al. (2020) for the Río Maitenes and Río Dunas catchments (pink dashed lines). Select representations are illustrated because there is no change between $0.2 \mathrm{ka}$ and $5 \mathrm{ka}$ (panel B), or $10 \mathrm{ka}$ and $13 \mathrm{ka}$ (panel C). No ice is present within the Río Dunas catchment in the last 13,000 years.

Río Dunas basin. However, ice reconstructions may not fully replicate the former extent of ice, especially in small basins or where relief is minimal.

\section{Discussion}

\subsection{Consideration of factors influencing delta size}

Climate and geography influence the amount of water and sediment available for delta construction. The bulk of coarse-grained delta growth occurs during peak flood events (e.g., McPherson et al., 1987; Winsemann et al., 2018). Flood conditions (magnitude and frequency) are governed by the precipitation amount, catchment size, and storage capacity of the basin.

\subsubsection{Micro-climate variations}

An obvious first-order explanation for the delta size range is the significant micro-climate differences across the upper Río Baker basin (section 2.2). However, delta size and annual precipitation amounts exhibit opposite longitudinal trends (Fig. 4). The largest deltas are not consistently associated with areas that receive higher precipitation. In fact, one of the largest delta suites at Lake General Carrera is Chile Chico, where the driest station is located $(0.22 \mathrm{~m} / \mathrm{y}$; Table 1$)$.
Admittedly, meteorological stations are preferentially located along the lakeshore, and there is no precipitation data at higher elevations. Therefore, the available meteorological data incompletely capture the precipitation within the catchment. An indirect measure of precipitation throughout the drainage basin is reflected in streamflow measurements. With only three stream gauges in the upper Baker River, we also consider modeled daily discharge for four sub-basins from Krogh et al. (2015) to fill in gaps in the observational record. Both maximum daily discharge and mean annual discharge decrease to the east (Tables 2-3; Fig. 4B), consistent with the latitudinal precipitation pattern. Neither precipitation nor the available river discharge record correlates with delta size.

\subsubsection{Catchment}

Geomorphology studies seek to establish linkages between landscape form and the processes that shape it. Arguably, the catchment-fan system is the most widely investigated to characterize size and shape as a function of hydrologic, geologic and climatic conditions (e.g., Harvey, 1989; Lecce, 1990; Blair and McPherson, 1994). Overwhelmingly, geomorphology investigations of the catchment-fan system have concentrated on alluvial fans, especially in arid environments with 
relatively few studies in humid settings (Blair and McPherson, 1994; Allen, 2008). The same sediment routing system is applicable to deltaic deposits, but few have been considered for geomorphic studies due to the difficulty in studying submerged deposits and the majority of deltaic studies have focused on facies associations (e.g., Bhattacharya, 2006; Winsemann et al., 2018). Furthermore, many delta investigations are in marine settings, and lacustrine deltas are lesser studied. The fan-shaped deposits at Lake General Carrera are technically alluvial fan deltas (McPherson et al., 1987; Postma, 1990), and are amenable to this type of scale analysis.

Fundamentally, as the catchment area increases, the sediment discharge also increases and yields larger fan area. A power law between drainage basin area $\left(A_{d}\right)$ and fan area $\left(A_{f}\right)$ is well established from multiple alluvial fan studies (e.g., Denny, 1965; Hooke, 1968; Bull, 1977; Lecce, 1990):

$$
A_{f}=c\left(A_{d}\right)^{\mathrm{n}}
$$

(Equation 5)

where $n$ is the slope of the regression line in a log-log plot of the two variables and the coefficient $c$ is a constant. A literature compilation of values of $c$ and $n$ from different geologic and climatic settings is graphically shown in figure 5B (Allen and Hovius, 1998, and references therein). The $n$ parameter is a measure of the rate of change in fan area with increasing catchment size, and typical values are close to unity (Bull, 1964; Denny, 1965). Some studies have suggested that lower slopes ( $n$ values) are associated with humid regions (dashed lines Fig. 5B; e.g., Mills, 1982; Kostaschuk et al., 1986). The coefficient $c$ is a measure of the fan spread, and varies in response to a range of geomorphic factors including climate, source rock lithology, and accommodation space. The interplay between these factors is complex, and the wide range in $c$ values from 0.1 to 2.4 has been attributed to various dominant variables on a case by case basis with no universal interpretation for $c$ (Blair and McPherson, 1994).

As expected, the scale of Lake General Carrera deltas is correlated with the catchment size (Fig. 5B). The power law regression (omitting the ill-constrained Ibáñez delta) yields $c=0.16, n=0.81$, and a good degree of fit $\left(R^{2}=0.93\right)$. In comparison to other published studies, the deltas at Lake General Carrera follow a similar trendline to alluvial fans on the east side of Death Valley, CA (Denny, 1965; Hooke and Rohrer,
1977). Few prior studies have included deposits or catchments larger than $\sim 100 \mathrm{~km}^{2}$, and the largest deltas at Lake General Carrera contribute to this knowledge gap.

The ratio of fan area to drainage basin area is the dimensionless parameter $\phi$ :

$$
\phi=\frac{A_{f}}{A_{d}}
$$

Equation 5 is based on mass balance in the sedimentary system. Phi values are between $0.1<\phi<10$ in the majority of published studies (Allen and Hovius, 1998). Phi values for deltas at Lake General Carrera (0.01 to 0.05$)$ are lower than this typical range. Differences in $\phi$ are related to inefficiencies such as sediment loss or storage in the catchment (Allen, 2008). Possible explanations for the low phi values at Lake General Carrera include sediment trapping in the catchment due to insufficient flow magnitude or vegetation, or sediment loss within the lake resulting from hyperpycnal flow dynamics or wave transport.

Delta size is strongly correlated with the retention of glaciers in catchments, as classified by the ice factor $X$. Figure 5A illustrates the trend of larger deltas corresponding to drainage basins with long-term presence of ice $(X=1)$. Likewise, smaller deltas are associated with minimal ice coverage in the catchment.

These observations suggest that ice-release floods are likely an important factor in explaining the delta size variability, in conjunction with basin size. Catchments with minor or no glaciers are typically defined by narrow canyons with limited areas for meltwater accumulation. In contrast, catchments that have glaciers typically have highelevation lakes or bowl-shaped depressions with breached margins from overspilling events. This added water storage capacity facilitates extreme flood events $\left(>600 \mathrm{~m}^{3} / \mathrm{s}\right)$ that promote delta growth with the flow capable of transporting boulder-size bedload across the delta plain to the river mouth (Bell, 2009).

\subsection{Comparison of derived intermittency factor to literature values}

Few studies have determined intermittency factor (Fig. 11). Published values for modern rivers 
$\left(I_{\mathrm{f}}=0.06-0.35\right)$ are directly determined for the Eel, Atchafalaya, Mississippi, Red, Minnesota, and Yellow Rivers (Sklar and Dietrich, 2004; Wright and Parker, 2005; Czuba and Foufoula-Georgiou, 2014; Naito et al., 2019). For a larger sample size, Hayden et al. (2021) computed the intermittency factor for 201 modern rivers based on published values of sediment flux (stream gauge data) and found values range from $8 \times 10^{-4}$ to 1.6 , with a median of 0.10 . Notably, the river dataset favored warmer climates and only a single site is in a cold climatic zone. Additionally, Hayden et al. (2021) calculated the intermittency factor for six sedimentary deposits associated with sand-bed rivers; compared to their results for modern river, the sedimentary deposits (fans and deltas) had a narrower range of intermittency factor values and a lower median value of 0.04 (Fig. 11).

Estimated intermittency values for the Lake General Carrera modern deltas (average $I_{\mathrm{f}}=2 \times 10^{-3}$ or $5 \times 10^{-4}$ based on extrapolated or measured delta volume, respectively) are substantially lower than the median intermittency factor for rivers and sedimentary deposits (Hayden et al., 2021). This result is expected for these coarse-grain deltas, because sediment is transported to the delta only a small fraction of the time. In contrast, sand-bed rivers transport sediment almost continually. A secondary explanation for the much lower intermittency factor values in this study is the cold climate, which retards sediment deposition for the majority of each year.

The subset of Lake General Carrera deltas with long-term ice storage in the catchment $(X=1)$ have higher values of intermittency factor compared to deltas sourced from basins without year-round ice $(X=0)$ (Fig. 11). The relative difference between these groups is approximately an order of magnitude for average intermittency factor: $I_{\mathrm{f}}=4 \times 10^{-3}$ versus $5 \times 10^{-4}$ using extrapolated delta volume (or $I_{\mathrm{f}}=1 \times 10^{-3}$ versus $2 \times 10^{-4}$ based on measured delta volume). This difference is due to the wider disparity in fan volume (more so than discharge), which we attribute to the role of ice-melt release floods in delta construction. As an example, the size difference of neighboring deltas at Río Maitenes $(X=1)$ and Río Dunas $(X=0)$ is the reason for a greater than four-fold disparity in the intermittency factor: $I_{\mathrm{f}}=1.4 \times 10^{-3}$ versus $3.2 \times 10^{-4}$ using extrapolated delta volume (alternatively $I_{\mathrm{f}}=4.3 \times 10^{-4}$ versus $9.6 \times 10^{-5}$ based on measured delta volume).

\section{Conclusions}

Stacked delta terrace sequences at Patagonian Lake General Carrera record lake level drops during the last $\sim 13 \mathrm{ka}$. Within a $<20,000 \mathrm{~km}^{2}$ area, there is a considerable variation in climatic zones and catchment geography. This setting affords the opportunity to examine the factors influencing delta growth as these deltas experienced a common lake history but differences in upland properties that influence flood magnitude and frequency.

As expected, the delta size is correlated with the catchment size. However, the delta size differences are inversely correlated with the pronounced longitudinal precipitation gradient across the lake. We find that stepped delta size is associated with the spaciotemporal distribution of glaciers. This link between larger deltas and glaciers suggests that catchment water storage promoted delta growth at those locations.

The exposed internal delta architecture reveals details about the magnitude and frequency of delta constructional events. The bulk of the deposit is cobble-rich, a clast size that is transportable in seasonal floods $\left(\sim 100-200 \mathrm{~m}^{3} / \mathrm{s}\right)$. In some deltas, the occurrence of meter-size boulders in individual topset layers is consistent with rare (decadal or likely longer intervals), discreet high magnitude $\left(>600 \mathrm{~m}^{3} / \mathrm{s}\right)$ flood events attributed to ice meltwater release. Thus, the Lake General Carrera deltas with long-term ice in their catchment have an additional mechanism to flush sediment in meltwater floods, resulting in larger delta areas, volumes, and intermittency factors. Absent the ice melt contribution (or as a minor component) in the overall system, deltas are smaller with an average intermittency factor almost an order of magnitude lower.

The progradation rate for the youngest deltas (T1) range from 0.04 to $0.8 \mathrm{~m} / \mathrm{yr}$, and appears to be slower than for older perched deltas (0.1-2 m/yr.). This trend is seemingly counter to the increased retreat rate of glaciers caused by climate change. The apparent rate change in delta growth may be due to restricted sediment supply or enhanced sediment loss over time (Bell, 2008).

\section{Acknowledgments}

This research was supported by NASA grants to R.M.E. Williams: NNX15AH46G from the Solar System Workings program and 80NSSC20K0944 from the Mars Data Analysis Program. The authors thank Dr. A. Hayden 
(California Council on Science and Technology) and Dr. M. Lamb (Caltech) for dialogue and data regarding intermittency factors. We appreciate conversation and participation in field work with Dr. G. de Achille (Istituto Nazionale Di Astrofisica, INAF, Observatorio Astronomico d'Abruzzo) as well as logistical support from J. Harrison of Patagonia Acres and M. Eby. We thank Maxar for providing commercial satellite data through the NextView Imagery End User License Agreement of the National Geospatial Intelligence Agency. This work utilized resources from the University of Colorado Boulder Research Computing Group, which is supported by the National Science Foundation (awards ACI-1532235 and ACI-1532236), the University of Colorado Boulder, and Colorado State University. The authors are grateful for the time and effort of the anonymous reviewers and Editor W. Vivallo, whose input improved the manuscript. Data supporting the conclusions presented is available in the figures and tables.

\section{References}

Allen, P.A. 2008. Time scales of tectonic landscapes and their sediment routing systems. In Landscape Evolution: Denudation, Climate and Tectonics Over Different Time and Space Scales (Gallagher, K.; Jones, S.J.; Wainwright, J.; editors). Geological Society of London, Special Publication 296: 7-28. doi: 10.144/SP296.2.

Allen, P.A.; Hovius, N. 1998. Sediment supply from landslide-dominated catchments: implications for basin-margin fans. Basin Research 10 (1): 19-35. doi: 10.1046/j.1365-2117.1998.00060.x.

Bell, C.M. 2008. Punctuated drainage of an icedammed Quaternary lake in southern South America. Geografiska Annaler 90 (1): 1-17. doi: 10.1111/j.14680459.2008.00330.x.

Bell, C.M. 2009. Quaternary lacustrine braid deltas on Lake General Carrera in southern Chile. Andean Geology 36 (1): 51-66. doi: 10.5027/andgeoV36n1-a04.

Bendle, J.M.; Thorndycraft, V.R; Palmer, A. 2017. The glacial geomorphology of the Lago Buenos Aires and Lago Pueyrredón ice lobes of central Patagonia. Journal of Maps 13 (2): 654-673. doi: 10.1080/17445647.2017.1351908.

Bhattacharya, J.P. 2006. Deltas. In Facies Models Revisited (Posamentier, H.W. ; Walker, R.G.; editors). SEPM Society for Sedimentary Geology, Special Publication 84: 237-292. Tulsa. doi: 10.2110/pec.06.84.0237.
Blair, T.C.; McPherson, J.G. 1994. Alluvial fan processes and forms. In Geomorphology of Desert Environments (Abrahams, A.D.; Parsons, A.J.; editors). Chapman and Hall: 54-402. London.

Bourgois, J.; Cisternas, M.E.; Bourles, R.; Didier, B.; Frutos, J. 2016. Geomorphic Records along the General Carrera (Chile)-Buenos Aires (Argentina) Glacial Lake $\left(46^{\circ}-48^{\circ} \mathrm{S}\right)$, Climate Inferences, and Glacial Rebound for the Past 7-9 ka. Journal of Geology 124 (1): 27-53. doi: $10.1086 / 684252$.

Bull, W.B. 1964. Geomorphology of segmented alluvial fans in western Fresno County, California. United States Geological Survey (U.S.G.S.) Professional Paper 352-E: 89-129. doi: 10.3133/pp352E.

Bull, W.B. 1977. The alluvial-fan environment. Progress in Physical Geography: Earth and Environment 1 (2): 222-270. doi: 10.1177/030913337700100202.

Costa, J.E. 1988. Rheologic, geomorphic, and sedimentologic differentiation of water floods, hyperconcentrated flows, and debris flows. In Flood Geomorphology (Baker, V.R.; Kochel, R.C.; Patton, P.C.; editors). John Wiley and Sons: 113-122. New York.

Czuba, J.A.; Foufoula-Georgiou, E. 2014. A network-based framework for identifying potential synchronizations and amplifications of sediment delivery in river basins. Water Resources Research 50 (5): 3826-3851. doi: 10.1002/2013WR014227.

Davies, B.J.; Darvill, C.M.; Lovell, H.; Bendle, J.M.; Dowdeswell, J.A.; Fabele, D.; García, J.-L.; Geiger, A.; Glasser, N.F.; Gheorghiu, D.M.; Harrison, S.; Hein, A.S.; Kaplan, M.R.; Martin, J.R.V.; Mendelova, M.; Palmer, A.; Pelto, M.; Rodés, Á.; Sagredo, E.A.; Smedley, R.K.; Smellie, J.L.; Thorndycraft, V.R. 2020. The evolution of the Patagonian Ice Sheet from $35 \mathrm{ka}$ to the present day (PATICE). Earth-Science Reviews 201 (103152): 77. doi: 10.1016/j.earscirev.2020.103152.

Denny, C.S. 1965. Alluvial fans in the Death Valley region, California and Nevada. United States Geological Survey Professional Paper 466: 62. doi: 10.3133/pp46.

Dietrich, W.E.; Palucis, M.C.; Williams, R.M.E.; Lewis, K.W.; Rivera-Hernández, F.; Sumner, D.Y. 2017. Fluvial gravels on Mars: Analysis and implications. In Gravel Bed Rivers: Processes and Disasters (Tsutsumi, D.; Laronne, J.; editors). WileyBlackwell Publishing Company: 755-776. Hoboken. doi: 10.1002/9781118971437.ch28.

Douglass, D.C.; Singer, B.S.; Kaplan, M.R.; Ackert, R.P.; Mickelson, D.M.; Caffee, M.W. 2005. Evidence of early Holocene glacial advances in southern South 
America from cosmogenic surface-exposure dating. Geology 33 (3): 267-240. doi: 10.1130/G21144.1.

Dussaillant, A.J.; Benito, G.; Buytaert, W.; Carling, P.; Meier, C.; Espinoza, F. 2010. Repeated glacial-lake outburst floods in Patagonia: an increasing hazard? Natural Hazards 54: 469-481. doi: 10.1007/s11069-009-9479-8.

Dussaillant, A.J.; Buytaert, W.; Meier, C.; Espinoza, F. 2012. Hydrological regime of remote catchments with extreme gradients under accelerated change: the Baker basin in Patagonia. Hydrological Sciences Journal 57 (8): 530-1542. doi: 10.1080/02626667.2012.726993.

Garreaud, R.; López, P.; Minvielle, M.; Rojas, M. 2013. Large-Scale Control on the Patagonian Climate. Journal of Climate 26 (1): 215-230. doi: 10.1175/JCLI-D-12-00001.1.

Giles, P.T. 2010. Investigating the use of alluvial fan volume to represent fan size in morphometric studies. Geomorphology 121: 317-328. doi: 10.1016/j.geomorph.2010.05.001.

Glasser, N.F.; Aniya, M.; Harrison, S.; Winchester, V. 2004. Late Pleistocene and Holocene palaeoclimate and glacier fluctuations in Patagonia. Global and Planetary Change 43: 79-101. doi:10.1016/j.gloplacha.2004.03.002.

Glasser, N.F.; Jansson, K.N.; Duller, G.A.T.; Singarayer, J.; Holloway, M.; Harrison, S. 2016. Glacial lake drainage in Patagonia (13-8 kyr) and response of the adjacent Pacific Ocean. Scientific Reports 6 (21064): 7 p. doi: $10.1038 /$ srep21064.

Gray, J.R.; Simões, F.J.M. 2008. Estimating sediment discharge: Appendix D. In Sedimentation engineering: processes, measurements, modeling, and practice, American Society of Civil Engineers: 1065-1068. Reston.

Harvey, A.M. 1989. The occurence and role of arid zone alluvial fans. In Arid Zone Geomorphology (Thomas, D.S.G.; editor). John Wiley and Sons: 136-158. New York.

Hayden, A.T.; Lamb, M.P.; McElroy, B.J. 2021. Constraining the timespan of fluvial activity from the intermittency of sediment transport on Earth and Mars: Ebro Basin, Spain. Geophysical Research Letters 48 (16): 1-13 doi: 10.1029/2021GL092598.

Hooke, R.L. 1968. Steady-state relationships on arid-region alluvial fans in closed basins. American Journal of Science 266: 609-629. doi: 10.2475/ajs.266.8.609.

Hooke, R.L.; Rohrer, W.L. 1977. Relative erodibility of source-area rock types, as determined from secondorder variations in alluvial-fan size. Geological Society of America Bulletin 88: 1177-1182. doi: 10.1130/0016-7606(1977)88<1177:REOSRT>2.0.CO;2.

Kostaschuk, R.A.; Macdonald, G.M.; Putnam, P.E. 1986. Depositional process and alluvial fan-drainage basin morphometric relationships near Banff, Alberta, Canada. Earth Surface Processes and Landforms 11 (5): 471-484. doi: 10.1002/esp.3290110502.

Krogh, S.A.; Pomeroy, J.W.; McPhee, J. 2015. Physically Based Mountain Hydrological Modeling Using Reanalysis Data in Patagonia. Journal of Hydrometeorology 16 (1): 172-193. doi: 10.1175/JHM-D-13-0178.1.

Lecce, S.A. 1990. The Alluvial Fan Problem. In Alluvial Fans: A Field Approach (Rachocki, A.H.; Church, M.; editors). John Wiley and Sons: 3-24. Holbroken.

Li, C.; Czapiga, M.J.; Eke, E.C.; Viparelli, E.; Parker, G. 2015. Variable Shields number model for river bankfull geometry: bankfull shear velocity is viscosity-dependent but grain size-independent. Journal of Hydraulic Research 53 (1): 36-48. doi: 10.1080/00221686.2014.939113.

Meier, W.J.-H.; Grießinger, J.; Hochreuther, P.; Braun, M.H. 2018. An updated multi-temporal glacier inventory for the Patagonian Andes with changes between the Little Ice Age and 2016. Earth Science 6 (62): 21. doi: 10.3389/feart.2018.00062.

McPherson, J.G.; Shanmugam, G.; Moiola, R.J. 1987. Fan-deltas and braid deltas: varieties of coarse-grained deltas. Geological Society of America Bulletin 99: 311-340. doi: 10.1130/0016-7606(1987)99<331:FA $\mathrm{BDVO}>2.0 . \mathrm{CO} ; 2$.

Mills, H.H. 1982. Piedmont-cove deposits of the Dellwood quadrangle, Great Smoky Mountains, North Carolina, USA. Zeitschrift für Geomorphologie 26: 163-178.

Naito, K.; Ma, H.; Nittrouer, J A.; Zhang, Y.; Wu, B.; Wang, Y.; Fu, X.; Parker. G. 2019. Extended EngelundHansen type sediment transport relation for mixtures based on the sand-silt-bed Lower Yellow River, China. Journal of Hydraulic Research 57 (6): 770-785. doi: 10.1080/00221686.2018.1555554.

Naranjo, J.A.; Stern, C.R. 1998. Holocene explosive activity of Hudson Volcano, southern Andes. Bulletin of Volcanology 59: 291-306. doi: 10.1007/s004450050193.

Paola, C.; Heller, P.L.; Angevine, C.L. 1992. The largescale dynamics of grain-size variation in alluvial basins, 1: Theory. Basin Research 42 (2): 73-90. doi: 10.1111/j.1365-2117.1992.tb00145.x.

Peel, M.C.; Finlayson, B.L.; McMahon, T.A. 2007. Updated world map of the Köppen-Geiger climate classification. Hydrology and Earth System Sciences 11 (2): 1633-1644. doi: 10.5194/hess-11-1633-2007.

Postma, G. 1990. Depositional architecture and facies of river and fan deltas: a synthesis. In Coarse-Grained Deltas (Colella, A.; Prior, D.B.; editors). John Wiley and Sons: 13-27. Hoboken. 
Sklar, L.S.; Dietrich, W.E. 2004. A mechanistic model for river incision into bedrock by saltating bed load. Water Resources Research 40: 21. doi: 10.1029/2003WR002496.

Stock, J.D. 2013. Waters divided: a history of alluvial fan research and a view of its future. In Treatise on Geomorphology (Shroder, E.W.J.; editor). Academic Press 9: 413-458. San Diego. doi: 10.1016/B978-0-12-374739-6.00249-9.

Trampush, S.M.; Huzurbazar, S.V.; McElroy, B. 2014. Empirical assessment of theory for bankfull characteristics of alluvial channels. Water Resources Research 50: 9211-9220. doi: 10.1002/2014WR015597.

Turner, K.J.; Fogwill, C.J.; McCulloch, R.D.; Sugden, D.E. 2005. Deglaciation of the eastern flank of the North Patagonian Icefield and associated continental-scale lake diversions. Geografiska Annaler, 87A (2): 263-374. doi: 10.1111/j.0435-3676.2005.00263.x.
Ulloa, H.; Mazzorana, B.; Batalla, R.J.; Jullian, C.; Iribarren-Anacona, P.; Barrientos, G.; Reid, B.; Oyarzun, C.; Schaefer, M.; Iroumé, A. 2018. Morphological characterization of a highly-dynamic fluvial landscape: The River Baker (Chilean Patagonia). Journal of South American Earth Sciences 86: 1-14. doi: 10.1016/j.jsames.2018.06.002.

Winsemann, J.; Lang, J.; Polom, U.; Loewer, M.; Igel, J.; Pollok, L.; Brandes, C. 2018. Ice-marginal forced regressive deltas in glacial lake basins: geomorphology, facies variability and large-scale depositional architecture. Boreas, 47 (4): 973-1002. doi: 10.1111/bor.12317.

Wolman, M.G. 1954. A method of sampling coarse bed material. American Geophysical Union, Transactions, 35 (6): 951-956. doi: 10.1029/TR035i006p00951.

Wright, S.; Parker, G. 2005. Modeling downstream fining in sandbed rivers. I: Formulation. Journal of Hydraulic Research, 43 (6): 613-620. doi: 10.1080/00221680509500381. 